WAPD-TM-1451

DOE RESEARCH AND DEVELOPMENT REPORT

\title{
CRITICAL HEAT FLUX TESTS WITH HIGH PRESSURE WATER IN AN INTERNALLY HEATED ANNULUS WITH ALTERNATING AXIAL HEAT FLUX DISTRIBUTION
}

(AWBA Development Program)

S. G. BEUS

D. A. HUMPHREYS

SEPTEMBER 1979

CONTRACT DE-AC11-76PNOOO14 


\section{DISCLAIMER}

This report was prepared as an account of work sponsored by an agency of the United States Government. Neither the United States Government nor any agency Thereof, nor any of their employees, makes any warranty, express or implied, or assumes any legal liability or responsibility for the accuracy, completeness, or usefulness of any information, apparatus, product, or process disclosed, or represents that its use would not infringe privately owned rights. Reference herein to any specific commercial product, process, or service by trade name, trademark, manufacturer, or otherwise does not necessarily constitute or imply its endorsement, recommendation, or favoring by the United States Government or any agency thereof. The views and opinions of authors expressed herein do not necessarily state or reflect those of the United States Government or any agency thereof. 


\section{DISCLAIMER}

Portions of this document may be illegible in electronic image products. Images are produced from the best available original document. 
WAPD-TM- 1451

CRITICAL HEAT FLUX TESTS WITH HIGH

PRESSURE WATER IN AN INTERNALLY HEATED

ANNULUS WITH ALTERNATING AXIAL HEAT FLUX DISTRIBUTION

(AWBA Development Program)

S. G. Beus

D. A. Humphreys

Contract No,: DE-ACII-76-PN00014

\author{
Sep tember 1979 \\ Printed in the United States of America \\ Available from the \\ National Technical Information Service \\ U. S. Department of Commerce \\ 5285 Port Royal Road \\ Springfield, Virginia 22151
}

NOTE

This document is an interim memorandum prepared primarily for internal reference and does not represent a final expression of the opinion of Westinghouse. When this memorandum is distributed externally, it is with the express understanding that Westinghouse makes no representation as to completeness, accuracy, or usability of information contained therein. 
This report was prepared as an account of work sponsored by the United States Government. Neither the United. States, nor the United States Department of Energy, nor any of their employees, nor any of their contractors, subcontractors, or their employees, makes any warranty, express or implied, or assumes any legal liability or responstbility for the accuracy, completeness or usefulness of any information, apparatus, product or process disclosed, or represents that its use would not infringe privately owned rightits. 
The Shippingport Atomic Power Station located in Shippingport, Pennsylvania was the first large-scale, central-station nuclear power plant in the United States and the first plant of such size in the world operated solely to produce electric power. This program was started in 1953 to confirm the practical application of nuclear power for large-scale electric power generation. It has provided much of the technology being used for design and operation of the commercial, centralstation nuclear power plants now in use.

Subsequent to development and successful operation of the Pressurized Water Reactor in the DOE-owned reactor plant at the Shippingport Atomic Power Station, the Atomic Energy Commission in 1965 undertook a research and development program to design and build a light Water Breeder Reactor core for operation in the Shippingport Station.

The objective of the Light Water Breeder Reactor (IWBR) program has been to develop a technology that would significantly improve the utilization of the nation's nuclear fuel resources employing the well-established water reactor technology. To achieve this objective, work has been directed toward analysis, design, component tests, and fabrication of a water-cooled, thorium oxide fuel cycle breeder reactor for installation and operation at the Shippingport Station. The LWBR core started operation in the Shippingport Station in the Fall of 1977 and is expected to be operated for about 3 to 4 years. At the end of this period, the core will be removed and the spent fuel shipped to the Naval Reactors Expended Core Facility for a detailed examination to verify core performance including an evaluation of breeding characteristics.

In 1976, with fabrication of the Shippingport IWBR core nearing completion, the Energy Research and Development Administration established the Advanced Water Breeder Applications (AWBA) program to develop and disseminate technical information which would assist U. S. industry in evaluating the LWBR concept for commercial-scale applications. The program will explore some of the problems that would be faced by industry in adapting technology confirmed in the LWBR program. Information to be developed includes concepts for commercial-scale prebreeder cores which would produce uranium-233 for light water breeder cores while producing electric power, improvements for breeder cores based on the technology developed to fabricate and operate the Shippingport LWBR core, and other information and technology to aid in evaluating commercial-scale application of the LWBR concept.

All three development programs (Pressurized Water Reactor, Light Water Breeder Reactor, and Advanced Water Breeder Applications) have been administered by the Division of Naval Reactors with the goal of developing practical improvements in the utilization of nuclear fuel resources for generation of electrical energy using water-cooled nuclear reactors.

Technical information developed under the Shippingport, LWBR, and AWBA programs has been and will continue to be pubiished in technical memoranda, one of which is this present report. 


\section{Section}

I. INTRODUCTION

II. TEST DESCRIPTION

III. INSTRUMENTATION

IV. TEST PROCEDURE

V. EXPERIMENTAL RESULTS

VI. CONCLUSIONS

Reference

Acknowledgements

Table 1 - Critical Heat Flux Data - Alternating. Heat Flux Test

Table 2 - Critical Heat Flux Data - Alternating Heat Flux CHF Test with Hot Patch

Figures $1-10$ 
Critical heat flux experiments were performed with an alternating heat flux profile in an internally heated annulus. The heated length was 84 inches with a square wave alternating heat flux profile over the last 12 inches having a maximum-to-average heat flux ratio of 1.76. Test data were obtained at pressures from 800 to 2000 psia, mass velocities from $0.25 \times 10^{6}$ to $2.8 \times 10^{6} \mathrm{lb} / \mathrm{hr}-\mathrm{ft}^{2}$ and inlet temperatures ranging from 400 to $600 \mathrm{~F}$. Two different electrically heated test sections were employed both with 72 inch uniform and 12 inch alternating heat flux sections. The second test section had a 0.44 inch hot patch with a peak-to-average heat flux ratio of 2.7 superimposed on the alternating flux profile at the exit end.

Critical heat flux results with the alternating heat flux profile and with the superimposed hot patch were shown to be equivalent to those obtained in previous tests with a uniform heat flux profile except for several data points at low mass velocity and high enthalpy for which there is an apparent experimental bias in the uniform heat flux results.

Critical Heat Flux Tests with. High Pressure Water

In An Internally Heated Annulus with Alternating Axial Heat Flux Distribution (AWBA Development Program).

\section{INTRODUCTION}

The Advanced Water Breeder Applications project at Bettis Atomic Power Laboratory is evaluating a number of prebreeder concepts to support the development of water-cooled breeder reactors initiated and currently being demonstrated with the Light Water Breeder Reactor at Shippingport, Prebreeder reactors would be required to produce the U-233 necessary for the operation of water-cooled breeder reactors which would burn thorium and $\mathrm{U}-233$.

One prebreeder concept involves the use of alternate thoria and urania peliets in a fuel rod that would be identical in size to fuel rods in existing commercial reactors. These rods could then be directly backfitted with a minimum of mechanical and hydraulic development and testing. At beginning of life only a small amount of the thermal power (on the order of 10\%) would 
be generated in the thorium. Neglecting axial conduction, the surface heat flux distribution would be a square wave. Axial conduction will smooth the heat flux distribution but the basic character will remain the same.

The testing described in this report was conducted to investigate the effect of this type of heat flux distribution, compared to a more uniform distribution, on the CHF power capability of a rod. The specific purpose of this experiment was to obtain a data base from which a preliminary evaluation of the $\mathrm{CHF}$ performance of a reactor using an alternating fuel pellet design could be made.

II. TEST DESCRIPTION

The electrically heated test section consisted of a 0.303 inch 0.D. 316 stainless steel tube with a 0.049 inch wall installed in a $0.518 \pm 0.007$ inch I.D. ceramic housing (see Figure 1). The diameter and tolerance on the I.D. are the mean and standard deviation of measurements from a group of ceramic tubes selected from the batch. The test section was centered within the ceramic housing by means of tube segment spacers (see Figure 1 and 2) at 6 axial levels along the 84 inch heated length with the uppermost spacer being located 13.0 inches below the end of the heated length. The ceramic housing was contained within a 1.0 inch $0 . D$. 316 stainless steel tube with a 0.083 inch wall which served as the backup housing for the test assembly.

The alternating heat flux effects were represented by fabricating a square wave electrical resistance path only over the upper section of the heated rod assembly as shown in Figure 2. The alternating high and low electrical resistance heated rod section was assembled by furnace brazing copper-nickel (Alloy 706) plugs to the inside of the stainless steel tubing. The stainless steel tubing wall thickness in this region was 0.025 inches.

The uniformly heated portion of the heated rod assembly was sized such that the heat flux emanating from its surface was equal to the mean heat flux from the shorter section tube containing the alternating resistors. As shown in Figure 2, the dimensions of the heated rod assembly were such that the nominal flat heat flux profile extended over the initial 72.00 inches of the test section, and the altemating heat flux profile was restricted to the final 12.00 inches.

Two nominally. identical heater rod assemblies were built and tested. One of the heater rod assemblies was reamed out at the upper end to a 
wall thickness of 0.016 inches to provide a local hot patch over the final 0.440 inches of heated length with a peak-to-average heat flux ratio of $2.7: 1$.

The uniform and alternating heater sections were butt welded together with 0.12 inch overlap as shown in Figure 2. Extensions were butt welded (also with 0.12 inch overlap) to each end of the heater tube rod assembly in order to provide an electrical connection between the tubes and the electrical terminals. The exit extension was a nickel tube with an outside taper which was fitted into a tapered hole in the exit electrical terminal. The CHF thermocouples were led out through the inside of the extension. The inlet extension was composed of a solid nickel piece connected by a length of braided copper cable, which allowed for differential thermal expansion between the heated rod assembly and the test section housing. The nickel connector was tapered and fit into a tapered hole in the inlet electrical terminal.

The detailed test section assembly is shown in Figure 3 including the exit end connections, electrical terminal and instrumentation. A flange assembly was bolted around the carbon steel electrical teminal. One side of the flange assembly was fastened to the test section pressure boundary by means of a 1.0 inch connector. The other side of the flange assembly was attached to a set of fittings which provided mountings for the exit and CHF thermocouples and the connection to the test loop. The inlet a $00 \mathrm{cmb} l y$ was very similar to the exit.

The as-built characteristics of the alternating heat flux section of the heater rod assembly were examined in a number of ways to make an accurate determination of the heat flux profile. Each rod section was $\mathrm{X}$-rayed after brazing to accurately locate the copper-nickel plugs. The plug length was found to be $0.345 \pm 0.005$ inches and the spaces between plugs (the high heat flux ctops) were folmd to be $0.335+0.01$ inch with the exception of one space centered at 6.375 inches from the end of the heated length of the first assembly which was 0.305 inches in length. The lengths of the alternating flux regions of the two assemblies were found to be 12.00 and 12.04 inches. 
The nominal heat flux profile in the alternating heat flux region is shown in Figure 4. An electrical resistance profile of the second assembly was determined by applying electrical power to the assembled rod and making a continuous voltage drop measurement along the length of the rod. The local-to-average heat flux ratios for the hot and cold sections averaged 1.76 and 0.197 with standard deviations of 4.1 and $10.8 \%$, respectively. The average maximum-to-minimum heat flux ratio for the region was 8.93 at approximately $100^{\circ} \mathrm{F}$, which extrapolates to approximately a $10: 1$ ratin at $700^{\circ} \mathrm{F}$.

The test section was installed in High Pressure Loop 22 of the Bettis Thermal and Hydraulic Laboratory. A general schematic of the test loop is shown in Figure 5. A Crocker-Wheeler direct current generator supplied electrical power to the test section with maximum ranges of 100 volts and 1300 amps. The loop water chemistry was controlled to a pH of about 7.0 and an oxygen content of less than $0.1 \mathrm{ppm}$. The loop and test section were designed for a pressure of $2500 \mathrm{psia}$ and a temperature of $636^{\circ} \mathrm{F}$. The test section was hydrostatically tested to 3750 psia at room temperature prior to installation in the loop.

\section{INSTRURENTATION}

Test section power was measured continuously by recording voltage drops across the test section and across a calibrated shunt which was used to measure current. Voltage and current readings are estimated to be accurate to within $\pm 1.0 \%$ and $\pm 0.8 \%$, respectively.

The flow rate was measured by reading the pressure drop across each of two nominally" identical orifices in series in one of two flow legs. The orifice diameters were 0.140 inch for nominal mass velocities below $1.0 \times 10^{6}$ $\mathrm{Lb} / \mathrm{hr}-\mathrm{ft} \mathrm{t}^{2}$ and $\mathrm{U} .30$ inch for higher nominal mass velocities. Each pair of orifices installed in its flow leg was calibrated with a weigh tank. Flow rates calculated from the two orifice readings agreed within $1 \%$ for the large orifices and within $3 \%$ for the small orifices. The water temperature at the orifices was measured by two thermocouples accurate to about $\pm 2{ }^{\circ} \mathrm{F}$.

Stainless steel sheathed chromel-alumel thermocouples were used for water temperature indication. Four water thermocouples were positioned in the flow, two upstream and two downstream of the heated length. Two asbestos-insulated chromel-alumel wall thermocouples were spot welded 
inside the stainless steel tubing near.the exit end of the test section as shown in Figure 2 for detection of $\mathrm{CHF}$.

Flow orifice pressure drops were measured by transducers connected across pressure taps located just upstream and downstream of the flow orifices.

The steady-state data acquisiton system consisted of automated tape recorders, oscillograph recorders for CHF thermcouple monitoring and strip chart recorders for generator current and test section voltage drop. The oscillographs were electrically coupled to the test section power supply such that the test section power was automatically reduced by $44 \%$ when a CHF temperature excursion was indicated. An Integrating Digital Voltmeter (IDVM) was used to detect all thermocouple and DP cell readings and these data were recorded on magnetic tape.

\section{TEST PROCEDURE}

There were four types of test runs performed, all at steady-state conditions after stabilizing the conditions in the loop for about 15 minutes. The types of runs were voltage pickup runs, heat balance runs, critical heat flux runs and runs made at $98 \%$ of critical heat flux. Four voltage pickup runs were made with each test section assembly to establish the correction factors to be applied to the wall thermocouple readings to account for the voltage pickup inherent in each thermocouple weld.

Eleven heat balance runs were made at subcooled conditions with low mass velocity to provide the basis for estimating the heat losses during all test runs. . Heat losses were correlated with inlet temperature and test section power.

The balance of the test consisted of dual test runs made at the experimentally determined critical heat flux (CHF) and at a heat flux just below CHF (98\%). The pressure, mass velocity and inlet temperature for the run were established and the heat flux was slowly raised to $75 \%$ of an estimated CHF value. The heat flux was then increased in $5 \%$ increments until CHF was indicated by an observed rapid increase of either of the wall thermocouple readings, at which time if possible a complece line of data was recorded. Following a CHF run, the power was reset to approximately $98 \%$ 
of the CHF power level and a complete line of data was recorded. These $98 \%$ runs served as a backup indication of nominal test section conditions for the CHF runs where a rapid CHF prevented the recording of a full line of data on magnetic tape.

Several replication runs were made throughout the test. In addition to the automatic recording of all data, oscillograph charts were also saved and examined.

V. EXPERIMENTAL RESULTS

\section{Altemating Heat Flux Data}

The CHF and $98 \%$ test data obtained in the alternating heat flux test section are presented in Table 1 where the types of runs are identified as $\mathrm{CHF}$ and 98 .

System pressures, mass velocities and inlet fluid temperatures were determined from instrumentation readings using standard data reduction techniques. The inlet enthalpy was obtained from the inlet temperature using fluid properties tables. The average channel heat flux was based on electrical power input as determined from voltage and current measurements. The exit enthalpy was calculated from heat balance equations using the average heat flux, inlet conditions and a small heat loss correstion haser on data from a series of heat balance runs.

To evaluate the CHF penalty due to an alternating heat flux profile compared to a uniform profile, a set of uniform heat flux data from a nominally identical test section was employed, This set of data was obtained from Keterence 1 and the two data sets are compared on a heat flux ratio basis in Figure 6 . The ratio of the average alternating heat flux to the average uniform heat flux for comparable CHF data points is plotted against mass velocity and against exit quality. Only those data points are displayed for which comparable uniform heat flux data were available.

In Figure 6 all of the data points except one lie within a $10 \%$ deviation band of unity. The one data point lies below the band at $1200 \mathrm{psia}, 1.0 \times 10^{6} \mathrm{lb} / \mathrm{hr}-\mathrm{ft}^{2}$ mass velocity and $500^{\circ} \mathrm{F}$ inlet temperature (Run No. 42). There is a trend of flux ratios approaching 1.10 at low mass velocity which shows up again at high quality. This trend was also observed 
in Reference 1 and is not judged to be a valid experimental result. It is believed that a portion of the uniform heat flux data base reported in Reference 1 has an experimental bias to low values of CHF. As a result the CHF ratios resulting from use of these erroneous data points are greater than 1.0 .

Alternating Heat Flux Data with Exit Hot Patch

The CHF and $98 \%$ test data obtained in the hot patch alternating heat flux test section are presented in Table 2. In this portion of the test, the pressures, mass velocities and inlet temperatures at CHF were not recorded and hence the backup values from the $98 \%$ runs are used for these quantities in the table.

The hot patch data are evaluated by comparison to the altemating heat flux data on a flux ratio basis in Figure 7. The ratio of the average test section heat flux from the hot patch altemating flux test to the average test section heat flux from the alternating flux test is plotted against mass velocity and against exit quality. Only those data points are displayed for which comparable fluid conditions were tested.

In Figure 7, al1 of the data points except one lie within a $10 \%$ deviation band of unity: The one data point lies above the band at $1200 \mathrm{psia}, 0.25 \times 10^{6} \mathrm{bb} / \mathrm{hr}-\mathrm{ft}^{2}$ mass velocity and $500^{\circ} \mathrm{F}$ inlet temperature (Run No. 168). It is noted that the mass velocities of the two test runs used to form the ratio in this case differed by about $3 \%$. There are no apparent trends of the data with either mass velocity or exit quality。 Figure 7 demonstrates conclusively that there was no CHF penalty in the test due to superimposing the subject hot patch on the alternating heat flux profile at the test section exit.

\section{Discussion}

Al1 of the CHF data obtained in both tests at four mass velocities are displayed in Figures 8,9 and 10 together with the uniform heat flux data from Reference 1 . The one data point with a heat flux ratio less than 0.90 referred to above appears in Figure 10. This data point is at a low flux level and does not appear to deviate substantially from the other data. A CHF penalty would most likely appear at higher heat fluxes and lower inlet temperatures. Since Run No. 64, on the same $1.0 \times 10^{6}$ mass velocity plot but with a lower inlet temperature, falls into the general data population, it is judged that Run No. 42 does not indicate a CHF penalty but only data scatter. 
The instrumentation errors inherent in this type of experimentation together with an inexact definition of the $\mathrm{CHF}$ phenomenon make it difficult to pinpoint CHF with accuracy. Experience has shown that a deviation of about $\pm 10 \%$ is not unusual in the experimental determination of critical heat flux power levels. Examination of the data reported leads to the conclusion that there was no significant CHF penalty due to the alternating heat flux profile with or without an exit hot patch.

VI. CONCLUSIONS

Critical heat tiux tests were performed with an alternating heat filux profile and with an exit hot patch superimposed upon an alternating heat flux profile. Seventy-three CHF points were obtained and compared to baseline data to determine the effect of the heat flux profiles on critical heat flux performance.

No significant CHF penalty due to the alternating heat flux profile was observed. In fact, for the range of variables tested, the critical heat flux performance of the alternating heat flux test section was indistinguishable within the accuracy of the experimental technique from that of a comparable uniformly heated test section except for several CHF points at low mass velocity and high enthalpy. It is believed that there is an experimental bias in the uniform heat flux data base for these conditions such that there would not be an actual increase in CHF for an alternating heat flux. Superposition of a 0.44 . inch hot patch of up to $\dot{2}, i: 1$ peak-to-average heat flux ratio on the test section had no discernable effect on the critical heat flux capability of the rod tested.

\section{Reference}

1. WAPD-TM-1419, "Critical Heat Flux Experiments with a Local Hot Patch in an Internally Heated Annulus," E. P. Mortimore, S. G. Beus, dated February 1979.

\section{Acknowledgements}

The authors gratefully acknowledge the assistance of $\mathrm{A}$. Weiss for designing the test, Thermal \& Hydraulics Lab personnel under the direction of Mr. C. J. Deal in conducting the tests, Ms. E. H. Burr in reducing the data and Ms. M. K. Gilmore in typing the manuscript. 
TABLE 1

Critical Heat Flux Data -

Alternating Heat Flux Test

\begin{tabular}{|c|c|c|c|c|c|c|c|}
\hline & & & MASS & & & AVERAGE & CALCU- \\
\hline $\begin{array}{l}\text { RUN } \\
\text { NO. }\end{array}$ & TYPE & $\begin{array}{l}\text { PFES- } \\
\text { (PSIA) }\end{array}$ & $\begin{array}{l}\text { VELOCYTY } \\
X 10-6 \\
\text { (LH/HR- } \\
\text { FTSO) }\end{array}$ & $\begin{array}{c}\text { INIEET } \\
\text { TEMPER- } \\
\text { ATIIRE } \\
\text { (DEG.F.) }\end{array}$ & $\begin{array}{l}\text { MEASURED } \\
\text { INLET } \\
\text { ENTHALPY } \\
\text { (BTÜLB). }\end{array}$ & $\begin{array}{l}\text { HEAT FLUX } \\
X \text { I }-6 \\
\text { (BTU/HR- } \\
\text { FTSQ) }\end{array}$ & $\begin{array}{l}\text { LATED } \\
\text { EXIT } \\
\text { ENTHALPY } \\
\text { (BTU/LB) }\end{array}$ \\
\hline $\begin{array}{l}32 \\
33\end{array}$ & $\begin{array}{l}\text { CHF } \\
98\end{array}$ & $\begin{array}{l}2000 \\
2000\end{array}$ & $\begin{array}{l}0.220 \\
0.220\end{array}$ & $\begin{array}{l}590.0 \\
598.9\end{array}$ & $\begin{array}{l}613.5 \\
613.3\end{array}$ & $\begin{array}{l}0.125 \\
0.122\end{array}$ & $\begin{array}{l}922.6 \\
914.8\end{array}$ \\
\hline $\begin{array}{l}30 \\
31\end{array}$ & $\begin{array}{l}\text { CHF } \\
98\end{array}$ & $\begin{array}{l}2000 \\
2000\end{array}$ & $\begin{array}{l}0.431 \\
0.431\end{array}$ & $\begin{array}{l}601.0 \\
601.4\end{array}$ & $\begin{array}{l}616.5 \\
617.1\end{array}$ & $\begin{array}{l}0.150 \\
0.148\end{array}$ & $\begin{array}{l}808.5 \\
806.4\end{array}$ \\
\hline $\begin{array}{l}28 \\
29\end{array}$ & $\begin{array}{l}\mathrm{CHF} \\
98\end{array}$ & $\begin{array}{l}2000 \\
2000\end{array}$ & $\begin{array}{l}0.899 \\
0.901\end{array}$ & $\begin{array}{l}60 \cap .1 \\
60 \cap .5\end{array}$ & $\begin{array}{l}615.1 \\
615.7\end{array}$ & $\begin{array}{l}0.244 \\
0.240\end{array}$ & $\begin{array}{l}767.7 \\
765.0\end{array}$ \\
\hline $\begin{array}{l}26 \\
27\end{array}$ & $\begin{array}{l}\text { CHF } \\
98\end{array}$ & $\begin{array}{l}2000 \\
2000\end{array}$ & $\begin{array}{l}1.79 \\
1.79\end{array}$ & $\begin{array}{l}590.4 \\
599.5\end{array}$ & $\begin{array}{l}614.1 \\
614.2\end{array}$ & $\begin{array}{l}0.372 \\
0.363\end{array}$ & $\begin{array}{l}731.9 \\
728.8\end{array}$ \\
\hline $\begin{array}{l}24 \\
25\end{array}$ & $\begin{array}{l}\mathrm{CHF} \\
98\end{array}$ & $\begin{array}{l}2000 \\
2000\end{array}$ & $\begin{array}{l}2.53 \\
2.53\end{array}$ & $\begin{array}{l}599.8 \\
599.7\end{array}$ & $\begin{array}{l}614.6 \\
614.6\end{array}$ & $\begin{array}{l}0.449 \\
0.437\end{array}$ & $\begin{array}{l}715.6 \\
712.7\end{array}$ \\
\hline $\begin{array}{l}16 \\
17\end{array}$ & $\begin{array}{l}\text { CHF } \\
98\end{array}$ & $\begin{array}{l}2000 \\
2000\end{array}$ & $\begin{array}{l}0.216 \\
0.216\end{array}$ & $\begin{array}{l}50 n .4 \\
500.3\end{array}$ & $\begin{array}{l}488.3 \\
488.1\end{array}$ & $\begin{array}{l}0.161 \\
0.156\end{array}$ & $\begin{array}{l}900.8 \\
888.0\end{array}$ \\
\hline 34 & $\mathrm{CHF}$ & 2000 & 0.218 & $50 \cap .2$ & 487.9 & 0.159 & 890.8 \\
\hline $\begin{array}{l}18 \\
19\end{array}$ & $\begin{array}{l}\text { CHF } \\
98\end{array}$ & $\begin{array}{l}2000 \\
2000\end{array}$ & $\begin{array}{l}0.426 \\
0.426\end{array}$ & $\begin{array}{l}50 \cap .5 \\
5 n 1.1\end{array}$ & $\begin{array}{l}488.4 \\
489.1\end{array}$ & $\begin{array}{l}0.233 \\
0.231\end{array}$ & $\begin{array}{l}795.0 \\
792.8\end{array}$ \\
\hline $\begin{array}{l}20 \\
21\end{array}$ & $\begin{array}{l}\text { CHF } \\
98\end{array}$ & $\begin{array}{l}2.000 \\
2000\end{array}$ & $\begin{array}{l}0.901 \\
0.901\end{array}$ & $\begin{array}{l}50 \cap .5 \\
500.3\end{array}$ & $\begin{array}{l}488.4 \\
488.1\end{array}$ & $\begin{array}{l}0.384 \\
0.376\end{array}$ & $\begin{array}{l}729.8 \\
724.7\end{array}$ \\
\hline $\begin{array}{l}96 \\
97\end{array}$ & $\begin{array}{l}\text { CHF } \\
98\end{array}$ & $\begin{array}{l}2000 \\
2000\end{array}$ & $\begin{array}{l}0.908 \\
0.908\end{array}$ & $\begin{array}{l}499.8 \\
500.3\end{array}$ & $\begin{array}{l}486.4 \\
488.1\end{array}$ & $\begin{array}{r}0.382 \\
0.371\end{array}$ & $\begin{array}{l}724.8 \\
720.0\end{array}$ \\
\hline $\begin{array}{l}22 \\
23\end{array}$ & $\begin{array}{l}\text { CHF } \\
98\end{array}$ & $\begin{array}{l}2000 \\
2000\end{array}$ & $\begin{array}{l}1.79 \\
1.79\end{array}$ & $\begin{array}{l}500.5 \\
500.5\end{array}$ & $\begin{array}{l}488.4 \\
488.4\end{array}$ & $\begin{array}{l}0.561 \\
0.548\end{array}$ & $\begin{array}{l}669.1 \\
662.7\end{array}$ \\
\hline $\begin{array}{l}70 \\
71\end{array}$ & $\begin{array}{l}\text { CHF } \\
98\end{array}$ & $\begin{array}{l}2000 \\
2000\end{array}$ & $\begin{array}{l}2.20 \\
2.20\end{array}$ & $\begin{array}{l}499.7 \\
499.9\end{array}$ & $\begin{array}{l}487.4 \\
487.6\end{array}$ & $\begin{array}{l}0.644 \\
0.630\end{array}$ & $\begin{array}{l}655.1 \\
651.3\end{array}$ \\
\hline $\begin{array}{l}48 \\
49\end{array}$ & $\begin{array}{l}\text { CHF } \\
98\end{array}$ & $\begin{array}{l}2000 \\
2000\end{array}$ & $\begin{array}{l}0.228 \\
0.228\end{array}$ & $\begin{array}{l}40 n .4 \\
40 n .3\end{array}$ & $\begin{array}{l}377.7 \\
377.6\end{array}$ & $\begin{array}{l}0.205 \\
0.198\end{array}$ & $\begin{array}{l}879.5 \\
863.2\end{array}$ \\
\hline $\begin{array}{l}50 \\
51\end{array}$ & $\begin{array}{l}\text { CHF } \\
98\end{array}$ & $\begin{array}{l}2000 \\
2000\end{array}$ & $\begin{array}{l}0.448 \\
0.448\end{array}$ & $\begin{array}{l}400.3 \\
400.2\end{array}$ & $\begin{array}{l}377.6 \\
377.5\end{array}$ & $\begin{array}{l}0.323 \\
0.316\end{array}$ & $\begin{array}{l}785.1 \\
776.1\end{array}$ \\
\hline $\begin{array}{l}52 \\
53\end{array}$ & $\begin{array}{l}\text { CHF } \\
98\end{array}$ & $\begin{array}{l}2000 \\
2000\end{array}$ & $\begin{array}{l}0.917 \\
0.916\end{array}$ & $\begin{array}{l}400.4 \\
400.9\end{array}$ & $\begin{array}{l}377.8 \\
375.2\end{array}$ & $\begin{array}{l}0.489 \\
0.483\end{array}$ & $\begin{array}{l}681.8 \\
678.6\end{array}$ \\
\hline 69 & MAX* & 2000 & 1.79 & 390.8 & 377.0 & 0.731 & 611.0 \\
\hline
\end{tabular}

* No CHF achieved at maximum power of generator. 
TABLE 1 (Continued)

\begin{tabular}{|c|c|c|c|c|c|c|c|}
\hline \multirow[b]{2}{*}{$\begin{array}{l}\text { RUN } \\
\text { NO. }\end{array}$} & \multirow[b]{2}{*}{ TYPE } & \multicolumn{3}{|c|}{ MASS } & \multicolumn{2}{|r|}{ AVERAGE } & \multirow[b]{2}{*}{$\begin{array}{l}\text { CALCU- } \\
\text { LATED } \\
\text { EXIT } \\
\text { ENTHALPY } \\
\text { (BTU/LB) }\end{array}$} \\
\hline & & $\begin{array}{l}\text { PRES- } \\
\text { (PSIA) }\end{array}$ & $\begin{array}{c}\text { VELOCTTY } \\
X 10-6 \\
\text { (LE/HR- } \\
F T S O)\end{array}$ & $\begin{array}{c}\text { INLET } \\
\text { TEMPER- } \\
\text { ATIIRE } \\
\text { (DEG・F・) }\end{array}$ & $\begin{array}{l}\text { MEASURED } \\
\text { INLET } \\
\text { ENTHALPY } \\
(B I U / L B)\end{array}$ & $\begin{array}{l}\text { HEAT FLUX } \\
\text { X IO }-6 \\
\text { (BTU/HR- } \\
\text { FTSQ) }\end{array}$ & \\
\hline $\begin{array}{l}36 \\
37\end{array}$ & $\begin{array}{l}\text { CHF } \\
98\end{array}$ & $\begin{array}{l}1600 \\
1600\end{array}$ & $\begin{array}{l}0.214 \\
0.213\end{array}$ & $\begin{array}{l}499.0 \\
499.1\end{array}$ & $\begin{array}{l}486.5 \\
486.6\end{array}$ & $\begin{array}{l}0.162 \\
0.158\end{array}$ & $\begin{array}{l}904.9 \\
892.8\end{array}$ \\
\hline $\begin{array}{l}92 \\
93\end{array}$ & $\begin{array}{l}\text { CHF } \\
98\end{array}$ & $\begin{array}{l}1600 \\
1600\end{array}$ & $\begin{array}{l}0.220 \\
0.221\end{array}$ & $\begin{array}{l}500.0 \\
500.1\end{array}$ & $\begin{array}{l}487.7 \\
487.8\end{array}$ & $\begin{array}{l}0.162 \\
0.157\end{array}$ & $\begin{array}{l}894.2 \\
880.2\end{array}$ \\
\hline $\begin{array}{l}38 \\
39\end{array}$ & $\begin{array}{l}\text { CHF } \\
98\end{array}$ & $\begin{array}{l}1600 \\
1600\end{array}$ & $\begin{array}{l}0.424 \\
0.425\end{array}$ & $\begin{array}{l}490.2 \\
499.2\end{array}$ & $\begin{array}{l}486.8 \\
486.8\end{array}$ & $\begin{array}{l}0.216 \\
0.209\end{array}$ & $\begin{array}{l}771.8 \\
761.6\end{array}$ \\
\hline $\begin{array}{l}40 \\
41\end{array}$ & $\begin{array}{l}\text { CHF } \\
98\end{array}$ & $\begin{array}{l}1600 \\
1600\end{array}$ & $\begin{array}{l}0.907 \\
0.907\end{array}$ & $\begin{array}{l}499.3 \\
499.1\end{array}$ & $\begin{array}{l}486.8 \\
486.7\end{array}$ & $\begin{array}{l}0.348 \\
0.342\end{array}$ & $\begin{array}{l}704.0 \\
700.3\end{array}$ \\
\hline $\begin{array}{l}94 \\
95\end{array}$ & $\begin{array}{l}\text { CHF } \\
98\end{array}$ & $\begin{array}{l}1600 \\
1600\end{array}$ & $\begin{array}{l}0.906 \\
0.906\end{array}$ & $\begin{array}{l}50 n .7 \\
501.0\end{array}$ & $\begin{array}{l}488.5 \\
488.8\end{array}$ & $\begin{array}{l}0.343 \\
0.338\end{array}$ & $\begin{array}{l}702.8 \\
700.1\end{array}$ \\
\hline $\begin{array}{l}72 \\
73\end{array}$ & $\begin{array}{l}\text { CHF } \\
98\end{array}$ & $\begin{array}{l}1600 \\
1600\end{array}$ & $\begin{array}{l}1.80 \\
1.80\end{array}$ & $\begin{array}{l}499.7 \\
499.7\end{array}$ & $\begin{array}{l}487 \cdot 3 \\
487.3\end{array}$ & $\begin{array}{l}11.539 \\
0.532\end{array}$ & $\begin{array}{l}658.1 \\
655.8\end{array}$ \\
\hline $\begin{array}{l}74 \\
75\end{array}$ & $\begin{array}{l}\text { CHF } \\
98\end{array}$ & $\begin{array}{l}1600 \\
1600\end{array}$ & $\begin{array}{l}2.17 \\
2.17\end{array}$ & $\begin{array}{l}500.6 \\
500.4\end{array}$ & $\begin{array}{l}488.4 \\
480.1\end{array}$ & $\begin{array}{l}0.606 \\
0.599\end{array}$ & $\begin{array}{l}647.9 \\
645.6\end{array}$ \\
\hline $\begin{array}{l}58 \\
59\end{array}$ & $\begin{array}{l}\text { CHF } \\
98\end{array}$ & $\begin{array}{l}1600 \\
1600\end{array}$ & $\begin{array}{l}0.227 \\
0.328\end{array}$ & $\begin{array}{l}40 n .6 \\
4 n 1.2\end{array}$ & $\begin{array}{l}377.5 \\
378.1\end{array}$ & $\begin{array}{l}0.198 \\
0.192\end{array}$ & $\begin{array}{l}865.3 \\
848.8\end{array}$ \\
\hline $\begin{array}{l}56 \\
57\end{array}$ & $\begin{array}{l}\text { CHF } \\
98\end{array}$ & $\begin{array}{l}1600 \\
1600\end{array}$ & $\begin{array}{l}0.448 \\
0.448\end{array}$ & $\begin{array}{l}39 R .8 \\
39 R .8\end{array}$ & $\begin{array}{l}375.6 \\
375.6\end{array}$ & $\begin{array}{l}0.288 \\
0.281\end{array}$ & $\begin{array}{l}738.6 \\
729.2\end{array}$ \\
\hline $\begin{array}{l}54 \\
55\end{array}$ & $\begin{array}{l}\text { EHF } \\
98\end{array}$ & $\begin{array}{l}1600 \\
1600\end{array}$ & $\begin{array}{l}0.920 \\
0.922\end{array}$ & $\begin{array}{l}399.2 \\
398.9\end{array}$ & $\begin{array}{l}376.0 \\
375.7\end{array}$ & $\begin{array}{l}0.470 \\
0.459\end{array}$ & $\begin{array}{l}666.8 \\
659.1\end{array}$ \\
\hline 68 & MAX* & 1600 & 1.79 & 394.8 & 376.7 & 0.733 & 611.0 \\
\hline
\end{tabular}

* -No CHF achieved at maximum power of generator. 
TABLE 1 (Continued)

\begin{tabular}{|c|c|c|c|c|c|c|c|}
\hline $\begin{array}{l}\text { RUN } \\
\text { NO. }\end{array}$ & PYPE & $\begin{array}{l}\text { PRESE } \\
\text { (PSIA) }\end{array}$ & $\begin{array}{c}\text { MASS } \\
\text { VELOCIFY } \\
X 10=6 \\
\text { PLB/HR. } \\
\text { FYSQI. }\end{array}$ & $\begin{array}{c}\text { INLET } \\
\text { TEMPER = } \\
\text { APURE } \\
\text { (DEG,F,) }\end{array}$ & $\begin{array}{l}\text { MEASURED } \\
\text { INLET } \\
\text { ENTHALPY } \\
\text { (BTU/LLB) }\end{array}$ & $\begin{array}{l}\text { AVERAGE } \\
\text { HEAT FLUX } \\
X \text { YO=6 } \\
\text { (BFU/HR- } \\
\text { FTSO) }\end{array}$ & $\begin{array}{l}\text { CALGUS } \\
\text { LATED } \\
\text { EXIT } \\
\text { ENTHALPY } \\
\text { (BTU/LB) }\end{array}$ \\
\hline $\begin{array}{l}46 \\
47\end{array}$ & $\begin{array}{l}\text { CHF } \\
98\end{array}$ & $\begin{array}{l}1200 \\
1200\end{array}$ & $\begin{array}{l}0.217 \\
0.217\end{array}$ & $\begin{array}{l}500,1 \\
500.1\end{array}$ & $\begin{array}{l}487,9 \\
487,9\end{array}$ & $\begin{array}{l}0.147 \\
0.1243\end{array}$ & $\begin{array}{l}863,5 \\
852,1\end{array}$ \\
\hline $\begin{array}{l}90 \\
91\end{array}$ & $\begin{array}{l}C H F \\
98\end{array}$ & $\begin{array}{l}1200 \\
1200\end{array}$ & $\begin{array}{l}0.226 \\
0.226\end{array}$ & $\begin{array}{l}499.5 \\
499.0\end{array}$ & $\begin{array}{l}487,3 \\
486 ! ?\end{array}$ & $\begin{array}{l}0,147 \\
0,144\end{array}$ & $\begin{array}{l}847,2 \\
837,9\end{array}$ \\
\hline $\begin{array}{l}44 \\
45\end{array}$ & $\begin{array}{l}C H F \\
98\end{array}$ & $\begin{array}{l}1200 \\
1200\end{array}$ & $\begin{array}{l}0.426 \\
0.426\end{array}$ & $\begin{array}{l}500,0 \\
409,6\end{array}$ & $\begin{array}{l}487,9 \\
487,4\end{array}$ & $\begin{array}{l}0,195 \\
0,190\end{array}$ & $\begin{array}{l}743,0 \\
735,1\end{array}$ \\
\hline $\begin{array}{l}42 \\
43\end{array}$ & $\begin{array}{l}\text { CHF } \\
98\end{array}$ & $\begin{array}{l}1200 \\
1200\end{array}$ & $\begin{array}{l}0.905 \\
0.906\end{array}$ & $\begin{array}{l}500,9 \\
501,1\end{array}$ & $\begin{array}{l}488,9 \\
489,1\end{array}$ & $\begin{array}{l}0.310 \\
0.302\end{array}$ & $\begin{array}{l}682,6 \\
677,1\end{array}$ \\
\hline $\begin{array}{l}88 \\
89\end{array}$ & $\oint_{8}^{H F}$ & $\begin{array}{l}1200 \\
1200\end{array}$ & $\begin{array}{l}0.894 \\
0.895\end{array}$ & $\begin{array}{l}501,3 \\
501: 6\end{array}$ & $\begin{array}{r}489.4 \\
489: ?\end{array}$ & 0,314 & $\begin{array}{l}687,6 \\
683,6\end{array}$ \\
\hline $\begin{array}{l}76 \\
.77\end{array}$ & $\begin{array}{l}\text { CHF } \\
98\end{array}$ & $\begin{array}{l}1200 \\
1200\end{array}$ & $\begin{array}{l}1.80 \\
1.80\end{array}$ & $\begin{array}{l}500,1 \\
500,0\end{array}$ & $\begin{array}{l}488.0 \\
487,9\end{array}$ & $\begin{array}{l}0,509 \\
0,501\end{array}$ & $\begin{array}{l}649,1 \\
646,7\end{array}$ \\
\hline $\begin{array}{l}78 \\
79\end{array}$ & $\begin{array}{l}\text { CHF } \\
98\end{array}$ & $\begin{array}{l}1200^{\circ} \\
1200\end{array}$ & $\begin{array}{l}2.03 \\
2.05\end{array}$ & $\begin{array}{l}500.7 \\
500.3\end{array}$ & $\begin{array}{l}488,6 \\
488, \frac{6}{2}\end{array}$ & $\begin{array}{l}0,543 \\
0,534\end{array}$ & $64 \frac{1}{37}: 5$ \\
\hline $\begin{array}{l}60 \\
62\end{array}$ & $\begin{array}{l}\text { CHF } \\
98\end{array}$ & $\begin{array}{l}1200 \\
1200\end{array}$ & $\begin{array}{l}0.227 \\
0.228\end{array}$ & $\begin{array}{l}400.0 \\
400.1\end{array}$ & $\begin{array}{l}376,5 \\
376,5\end{array}$ & $\begin{array}{l}0,187 \\
0,181\end{array}$ & $\begin{array}{l}830,9 \\
820,0\end{array}$ \\
\hline $\begin{array}{l}62 \\
63\end{array}$ & $\begin{array}{l}\text { CHF } \\
98\end{array}$ & $\begin{array}{l}1200 \\
1200\end{array}$ & $\begin{array}{l}0.447 \\
0.446\end{array}$ & $\begin{array}{l}399,4 \\
399,1\end{array}$ & $\begin{array}{l}375,6 \\
375,5\end{array}$ & $\begin{array}{l}0,270 \\
0,264\end{array}$ & $716: 0$ \\
\hline $\begin{array}{l}64 \\
65\end{array}$ & $\begin{array}{l}\text { CHF } \\
98\end{array}$ & $\begin{array}{l}1200 \\
1200\end{array}$ & $\begin{array}{l}0.890 \\
0.892\end{array}$ & $\begin{array}{l}399.3 \\
399.2\end{array}$ & $\begin{array}{l}375,7 \\
373,5\end{array}$ & $\begin{array}{l}0,434 \\
0,425\end{array}$ & $\begin{array}{l}652,9 \\
644,2\end{array}$ \\
\hline $\begin{array}{l}66 \\
67\end{array}$ & $\begin{array}{l}\text { CHF } \\
98\end{array}$ & $\begin{array}{l}1200 \\
1200\end{array}$ & $\begin{array}{l}1.80 \\
1.79\end{array}$ & $\begin{array}{l}399,2 \\
399,6\end{array}$ & $\begin{array}{l}375,6 \\
376,1\end{array}$ & $\begin{array}{l}0,725 \\
0,710\end{array}$ & $\begin{array}{l}607,4 \\
603,4\end{array}$ \\
\hline
\end{tabular}


TABLE 1 (Continued)

\begin{tabular}{|c|c|c|c|c|c|c|c|}
\hline & & & MASS & 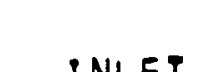 & $M=A S U$ SEI & AVERAGE & $\begin{array}{l}\text { CALCU } \\
\text { LATED }\end{array}$ \\
\hline RUN & & PRES - & ILETHR= & $\begin{array}{c}\text { TEMPER- } \\
\text { A PURE }\end{array}$ & $\begin{array}{l}\text { INLET } \\
\text { ENTHALPY }\end{array}$ & $\begin{array}{l}X \\
\text { (B } \$ O O=6 \\
\end{array}$ & $\begin{array}{l}\text { EXIT } \\
\text { ENTHALPY }\end{array}$ \\
\hline No." & TYPE & (PS|A) & $F T S O S$ & $(D E G, F)$, & (BTU/LB) & FTSO) & $(B T \cup / L B)$ \\
\hline $\begin{array}{l}80 \\
81\end{array}$ & $\begin{array}{l}\text { CHF } \\
98\end{array}$ & $\begin{array}{l}800 \\
800\end{array}$ & $\begin{array}{l}0.225 \\
0.225\end{array}$ & $\begin{array}{l}401,1 \\
401: 0\end{array}$ & $\begin{array}{l}376,9 \\
376,8\end{array}$ & $\begin{array}{l}0.161 \\
0.155\end{array}$ & $\begin{array}{l}773,3 \\
758,1\end{array}$ \\
\hline $\begin{array}{l}82 \\
83\end{array}$ & ${ }_{98}^{C H F}$ & $\begin{array}{l}800 \\
800\end{array}$ & $\begin{array}{l}0.446 \\
0.445\end{array}$ & $39.9 \%$ & 375,3 & $\begin{array}{l}0,236 \\
0 ! ? 20 \\
0\end{array}$ & $\begin{array}{l}672,7 \\
603,8\end{array}$ \\
\hline $\begin{array}{l}84 \\
85\end{array}$ & $\oint_{8}^{H F}$ & $\begin{array}{l}800 \\
800\end{array}$ & $\begin{array}{l}0.898 \\
0.896\end{array}$ & 399.5 & $375: 2$ & $\begin{array}{l}0,386 \\
0,376\end{array}$ & $\begin{array}{l}619,6 \\
613,4\end{array}$ \\
\hline $\begin{array}{l}86 \\
87\end{array}$ & $\begin{array}{l}\text { CHF } \\
98\end{array}$ & $\begin{array}{l}800 \\
800\end{array}$ & $\begin{array}{l}1.78 \\
1.78\end{array}$ & $\begin{array}{l}400,8 \\
400,6\end{array}$ & $\begin{array}{l}376,7 \\
376,4\end{array}$ & $\begin{array}{l}0,657 \\
0,643\end{array}$ & $\begin{array}{l}587,4 \\
582,5\end{array}$ \\
\hline
\end{tabular}


TABLE 2

Critical Heat Flux Data -

Alternating Heat Flux CHF Test with Hot Patch

\begin{tabular}{|c|c|c|c|c|c|c|c|}
\hline & . & & $\begin{array}{c}\text { MASS } \\
\text { VELOCITY }\end{array}$ & INLET & MEASUKED & $\begin{array}{l}\text { AVERAGE } \\
\text { HEAT FLUX }\end{array}$ & $\begin{array}{l}\text { CALCU: } \\
\text { LATED }\end{array}$ \\
\hline RUN & & PRES - & $\begin{array}{l}X 10-6 \\
R L B / H R-\end{array}$ & $\begin{array}{c}\text { TEMPER - } \\
\text { A PURE }\end{array}$ & $\begin{array}{l}\text { INLET } \\
\text { ENTHALPY }\end{array}$ & $\begin{array}{l}X 10=6 \\
(B T U / H R-\end{array}$ & $\begin{array}{l}\text { EXIT } \\
\text { ENTHALPY }\end{array}$ \\
\hline NO. & PYPE & (PSIA) & FTSOS & $(D E G, F)$, & (BTU/LB). & FTsOi & (BTU/LA) \\
\hline $\begin{array}{l}113 \\
114\end{array}$ & $\begin{array}{l}\text { CHF } \\
98\end{array}$ & $\begin{array}{l}2000 \\
2000\end{array}$ & $\begin{array}{l}0.233 \\
0.233\end{array}$ & $\begin{array}{l}599.5 \\
599: 5\end{array}$ & $\begin{array}{r}614,3 \\
614,3\end{array}$ & $\begin{array}{l}0.123 \\
0.120\end{array}$ & $\begin{array}{l}902.0 \\
895 ; 0\end{array}$ \\
\hline $\begin{array}{l}115 \\
116\end{array}$ & $\begin{array}{l}\text { CHF } \\
98\end{array}$ & $\begin{array}{l}2000 \\
2000\end{array}$ & $\begin{array}{l}0.448 \\
0.448\end{array}$ & $\begin{array}{l}600.0 \\
600.0\end{array}$ & $\begin{array}{r}615,0 \\
\quad 615,0\end{array}$ & $\begin{array}{l}0.156 \\
0.156\end{array}$ & $\begin{array}{l}807.2 \\
806,6\end{array}$ \\
\hline $\begin{array}{l}117 \\
118\end{array}$ & $\begin{array}{l}\text { CHF } \\
98\end{array}$ & $\begin{array}{l}2000 \\
2000\end{array}$ & $\begin{array}{l}0.902 \\
0.902\end{array}$ & $\begin{array}{l}596,8 \\
596,8\end{array}$ & $\begin{array}{l}610,2 \\
610,2\end{array}$ & $\begin{array}{l}0.244 \\
0.240\end{array}$ & $\begin{array}{l}761.9 \\
759: 4\end{array}$ \\
\hline $\begin{array}{l}119 \\
120\end{array}$ & $\begin{array}{l}\text { CHF } \\
98\end{array}$ & $\begin{array}{l}2000 \\
2000\end{array}$ & $\begin{array}{l}1.79 \\
1.79\end{array}$ & $\begin{array}{l}599.5 \\
599.5\end{array}$ & $\begin{array}{l}614,3 \\
614,3\end{array}$ & $\begin{array}{l}0.360 \\
0.352\end{array}$ & $\begin{array}{l}728.2 \\
725 ; 7\end{array}$ \\
\hline $\begin{array}{l}131 \\
132\end{array}$ & $\begin{array}{l}\text { CHF } \\
98\end{array}$ & $\begin{array}{l}2000 \\
2000\end{array}$ & $\begin{array}{l}2.51 \\
2.51\end{array}$ & $\begin{array}{l}599.5 \\
599.5\end{array}$ & $\begin{array}{l}614,2 \\
614,2\end{array}$ & $\begin{array}{l}0.441 \\
0.432\end{array}$ & $\begin{array}{l}713.9 \\
711,9\end{array}$ \\
\hline $\begin{array}{l}121 \\
122\end{array}$ & $\begin{array}{l}\text { CHF } \\
98\end{array}$ & $\begin{array}{l}2000 \\
2000\end{array}$ & $\begin{array}{l}0.228 \\
0.228\end{array}$ & $\begin{array}{l}499.5 \\
499.5\end{array}$ & $\begin{array}{l}487,1 \\
487: 1\end{array}$ & $\begin{array}{l}n .160 \\
0.154\end{array}$ & $\begin{array}{l}880.8 \\
866 ; 0\end{array}$ \\
\hline $\begin{array}{l}123 \\
124\end{array}$ & $\begin{array}{l}\text { CHF } \\
98\end{array}$ & $\begin{array}{l}2000 \\
2000\end{array}$ & $\begin{array}{l}0.451 \\
0.451\end{array}$ & $\begin{array}{l}499,9 \\
499.9\end{array}$ & $\begin{array}{l}487,7 \\
487: 7\end{array}$ & $\begin{array}{l}0.249 \\
0.242\end{array}$ & $\begin{array}{l}798.4 \\
789 ; 7\end{array}$ \\
\hline $\begin{array}{l}125 \\
126\end{array}$ & $\begin{array}{l}\text { CHF } \\
98\end{array}$ & $\begin{array}{l}2000 \\
2000\end{array}$ & $\begin{array}{l}0.907 \\
0.907\end{array}$ & $\begin{array}{l}499.6 \\
499.6\end{array}$ & $\begin{array}{l}487,4 \\
487,4\end{array}$ & $\begin{array}{l}0.383 \\
0.372\end{array}$ & $726: 4$ \\
\hline $\begin{array}{l}127 \\
128\end{array}$ & $\begin{array}{l}\text { CHF } \\
98\end{array}$ & $\begin{array}{l}2000 \\
2000\end{array}$ & $\begin{array}{l}1.79 \\
1.79\end{array}$ & $\begin{array}{l}499,5 \\
499,5\end{array}$ & $\begin{array}{l}487,2 \\
487,2\end{array}$ & $\begin{array}{l}0,572 \\
0,567\end{array}$ & $\begin{array}{l}669.2 \\
667.6\end{array}$ \\
\hline $\begin{array}{l}129 \\
130\end{array}$ & $\begin{array}{l}\text { CHF } \\
98\end{array}$ & $\begin{array}{l}2000 \\
2000\end{array}$ & $\begin{array}{l}2.19 \\
2.19\end{array}$ & $\begin{array}{l}499,3 \\
499,3\end{array}$ & $\begin{array}{l}487.0 \\
487.0\end{array}$ & $\begin{array}{l}0.618 \\
0.605\end{array}$ & $\begin{array}{l}648.1 \\
644,7\end{array}$ \\
\hline $\begin{array}{l}155 \\
156\end{array}$ & $\begin{array}{l}\mathrm{CHF} \\
98\end{array}$ & $\begin{array}{l}2000 \\
2000\end{array}$ & $\begin{array}{l}0.221 \\
0.221\end{array}$ & $\begin{array}{l}399,6 \\
399,6\end{array}$ & $\begin{array}{l}376,8 \\
376,8\end{array}$ & $\begin{array}{l}0,196 \\
0.189\end{array}$ & $\begin{array}{l}871.6 \\
853 ; 9\end{array}$ \\
\hline $\begin{array}{l}158 \\
159\end{array}$ & $\begin{array}{l}\text { CHF } \\
98\end{array}$ & $\begin{array}{l}2000 \\
2000\end{array}$ & $\begin{array}{l}0.447 \\
0.447\end{array}$ & $\begin{array}{l}398,6 \\
398,6\end{array}$ & $\begin{array}{l}375,8 \\
375,8\end{array}$ & $\begin{array}{l}0.326 \\
0.318\end{array}$ & $\begin{array}{l}787.9 \\
777: 8\end{array}$ \\
\hline $\begin{array}{l}160 \\
161\end{array}$ & $\begin{array}{l}\text { CHF } \\
98\end{array}$ & $\begin{array}{l}2000 \\
2000\end{array}$ & $\begin{array}{l}0.898 \\
0.898\end{array}$ & $\begin{array}{l}398,0 \\
398,0\end{array}$ & $\begin{array}{l}375,1 \\
375,1\end{array}$ & $\begin{array}{l}0,484 \\
0,462\end{array}$ & $\begin{array}{l}681.9 \\
668,0\end{array}$ \\
\hline
\end{tabular}


TABLE 2 (Continued)

\begin{tabular}{|c|c|c|c|c|c|c|c|}
\hline $\begin{array}{l}\text { RUN } \\
\text { NO. }\end{array}$ & TYPE & $\begin{array}{l}\text { PRES - } \\
\text { (PSIA) }\end{array}$ & $\begin{array}{l}\text { MASS } \\
\text { VELOCITY } \\
\text { X 1O-6 } \\
\text { (LB/HR- } \\
\text { FTSO) }\end{array}$ & $\begin{array}{c}\text { INLET } \\
\text { TEMPER- } \\
\text { ATURE } \\
\text { (DEG.F.) }\end{array}$ & $\begin{array}{l}\text { MEASURED } \\
\text { INLET } \\
\text { ENTHALPY } \\
\text { (BTU/LB) }\end{array}$ & $\begin{array}{l}\text { AVERAGE } \\
\text { HEAT FLUX } \\
\text { X } 10-6 \\
\text { (BTU/HR- } \\
\text { FTSQ) }\end{array}$ & $\begin{array}{l}\text { CALCU- } \\
\text { LATED } \\
\text { EXIT } \\
\text { ENTHALPY } \\
\text { (BTU/LB) }\end{array}$ \\
\hline $\begin{array}{l}139 \\
140\end{array}$ & $\begin{array}{l}\text { CHF } \\
9 B\end{array}$ & $\begin{array}{l}1600 \\
1600\end{array}$ & $\begin{array}{l}0.223 \\
0.223\end{array}$ & $\begin{array}{l}499.9 \\
499.9\end{array}$ & $\begin{array}{l}487.6 \\
487.6\end{array}$ & $\begin{array}{l}0.159 \\
0.154\end{array}$ & $\begin{array}{l}882.2 \\
869.8\end{array}$ \\
\hline $\begin{array}{l}137 \\
138\end{array}$ & $\begin{array}{l}\mathrm{CHF} \\
2 \mathrm{O}\end{array}$ & $\begin{array}{l}1600 \\
1600\end{array}$ & $\begin{array}{l}0.448 \\
0.448\end{array}$ & $\begin{array}{l}500.3 \\
500 \cdot 3\end{array}$ & $\begin{array}{l}488.0 \\
488.0\end{array}$ & $\begin{array}{l}0.222 \\
0.217\end{array}$ & $\begin{array}{l}765.4 \\
759.2\end{array}$ \\
\hline $\begin{array}{l}141 \\
142\end{array}$ & $\begin{array}{l}\text { CHF } \\
98\end{array}$ & $\begin{array}{l}1600 \\
1600\end{array}$ & $\begin{array}{l}0.900 \\
0.900\end{array}$ & $\begin{array}{l}500.0 \\
500.0\end{array}$ & $\begin{array}{l}487.7 \\
487.7\end{array}$ & $\begin{array}{l}0.337 \\
0.329\end{array}$ & $\begin{array}{l}699.2 \\
694.2\end{array}$ \\
\hline $\begin{array}{l}143 \\
144\end{array}$ & $\begin{array}{l}\text { CHF } \\
98\end{array}$ & $\begin{array}{l}1600 \\
1600\end{array}$ & $\begin{array}{l}1.80 \\
1.80\end{array}$ & $\begin{array}{l}500 \cdot 3 \\
500 \cdot 3\end{array}$ & $\begin{array}{l}488.0 \\
488.0\end{array}$ & $\begin{array}{l}0.515 \\
0.50 .3\end{array}$ & $\begin{array}{l}651.3^{-} \\
647.5\end{array}$ \\
\hline $\begin{array}{l}145 \\
146\end{array}$ & $\begin{array}{l}\text { CHF } \\
98\end{array}$ & $\begin{array}{l}1600 \\
1600\end{array}$ & $\begin{array}{l}2.15 \\
2.15\end{array}$ & $\begin{array}{l}500.4 \\
500.4\end{array}$ & $\begin{array}{l}488.2 \\
488.2\end{array}$ & $\begin{array}{l}0.639 \\
0.625\end{array}$ & $\begin{array}{l}658.1 \\
654.4\end{array}$ \\
\hline $\begin{array}{l}247 \\
148\end{array}$ & $\begin{array}{l}\text { CHF } \\
98\end{array}$ & $\begin{array}{l}1600 \\
1600\end{array}$ & $\begin{array}{l}0.222 \\
0.222\end{array}$ & $\begin{array}{l}400 \cdot 7 \\
400.7\end{array}$ & $\begin{array}{l}377.6 \\
377.6\end{array}$ & $\begin{array}{l}0.185 \\
0.180\end{array}$ & $\begin{array}{l}841.2 \\
828.7\end{array}$ \\
\hline $\begin{array}{l}149 \\
150\end{array}$ & $\begin{array}{l}\text { CHF } \\
98\end{array}$ & $\begin{array}{l}1600 \\
1600\end{array}$ & $\begin{array}{l}0.447 \\
0.447\end{array}$ & $\begin{array}{l}399.4 \\
399.4\end{array}$ & $\begin{array}{l}376 \cdot 3 \\
376 \cdot 3\end{array}$ & $\begin{array}{l}0.288 \\
0.282\end{array}$ & $\begin{array}{l}739.2 \\
731.6\end{array}$ \\
\hline $\begin{array}{l}151 \\
152\end{array}$ & $\begin{array}{l}\text { CHF } \\
98\end{array}$ & $\begin{array}{l}1600 \\
1600\end{array}$ & $\begin{array}{l}0.892 \\
0.892\end{array}$ & $\begin{array}{l}400.6 \\
400.6\end{array}$ & $\begin{array}{l}377.5 \\
377.5\end{array}$ & $\begin{array}{l}0.485 \\
0.476\end{array}$ & $\begin{array}{l}686.8 \\
681 \cdot 1\end{array}$ \\
\hline 153 & MAX & $* 1600$ & 1.79 & 400.3 & 377.2 & 0.716 & 605.9 \\
\hline
\end{tabular}

* No CHF achieved at maximum power of generator. 
TABLE 2 (Continued)

\begin{tabular}{|c|c|c|c|c|c|c|c|}
\hline $\begin{array}{l}\text { RUN } \\
\text { NO. . }\end{array}$ & TYPE & $\begin{array}{l}\text { PRES- } \\
\text { (PSIA) }\end{array}$ & $\begin{array}{l}\text { MASS } \\
\text { VELOCITY } \\
X 10-6 \\
\text { (LB/HR- } \\
\text { FTSQ) }\end{array}$ & $\begin{array}{c}\text { INLET } \\
\text { TEMPER- } \\
\text { ATURE } \\
\text { (DEG.F.) }\end{array}$ & $\begin{array}{l}\text { MEASURED } \\
\text { INLET } \\
\text { ENTHALPY } \\
\text { (BTU/LLB) }\end{array}$ & $\begin{array}{l}\text { AVERAGE } \\
\text { HEAT FLUX } \\
\text { X IO-G } \\
\text { (BTU/HR- } \\
\text { FTSQ) }\end{array}$ & $\begin{array}{l}\text { CALCU- } \\
\text { LATED } \\
\text { EXIT } \\
\text { ENTHALPY } \\
\text { (BTU/LB) }\end{array}$ \\
\hline $\begin{array}{l}168 \\
169\end{array}$ & $\begin{array}{l}\text { CHF } \\
98\end{array}$ & $\begin{array}{l}1200 \\
1200\end{array}$ & $\begin{array}{l}0.224 \\
0.224\end{array}$ & $\begin{array}{l}500 \cdot 1 \\
500 \cdot 1\end{array}$ & $\begin{array}{l}488.0 \\
488.0\end{array}$ & $\begin{array}{l}0.163 \\
0.157\end{array}$ & $\begin{array}{l}891.3 \\
875.7\end{array}$ \\
\hline $\begin{array}{l}170 \\
171\end{array}$ & $\begin{array}{l}\text { CHF } \\
98\end{array}$ & $\begin{array}{l}1200 \\
1200\end{array}$ & $\begin{array}{l}0.447 \\
0.447\end{array}$ & $\begin{array}{l}499.7 \\
499.7\end{array}$ & $\begin{array}{l}487.5 \\
487.5\end{array}$ & $\begin{array}{l}0.211 \\
0.206\end{array}$ & $\begin{array}{l}753.4 \\
745.8\end{array}$ \\
\hline $\begin{array}{l}72 \\
73\end{array}$ & $\begin{array}{l}\text { CHF } \\
98\end{array}$ & $\begin{array}{l}1200 \\
1200\end{array}$ & $\begin{array}{l}0.894 \\
0.894\end{array}$ & $\begin{array}{l}499.8 \\
499.8\end{array}$ & $\begin{array}{l}487.6 \\
487.6\end{array}$ & $\begin{array}{l}0.324 \\
0.318\end{array}$ & $\begin{array}{l}692.8 \\
689.0\end{array}$ \\
\hline $\begin{array}{l}174 \\
175\end{array}$ & $\begin{array}{l}\text { CHF } \\
98\end{array}$ & $\begin{array}{l}1200 \\
1200\end{array}$ & $\begin{array}{l}1.80 \\
1.80\end{array}$ & $\begin{array}{l}500 \cdot 0 \\
500 \cdot 0\end{array}$ & $\begin{array}{l}487.8 \\
487.8\end{array}$ & $\begin{array}{l}0.476 \\
0.462\end{array}$ & $\begin{array}{l}639.4 \\
634.9\end{array}$ \\
\hline $\begin{array}{l}176 \\
177\end{array}$ & $\begin{array}{l}\text { CHF } \\
98\end{array}$ & $\begin{array}{l}1200 \\
1200\end{array}$ & $\begin{array}{l}2.01 \\
2.01\end{array}$ & $\begin{array}{l}500 \cdot 3 \\
500 \cdot 3\end{array}$ & $\begin{array}{l}488.2 \\
488.2\end{array}$ & $\begin{array}{l}0.516 \\
0.497\end{array}$ & $\begin{array}{l}634.3 \\
628.9\end{array}$ \\
\hline $\begin{array}{l}162 \\
163\end{array}$ & $\begin{array}{l}\mathrm{CHF} \\
98\end{array}$ & $\begin{array}{l}1200 \\
1200\end{array}$ & $\begin{array}{l}0.228 \\
0.228\end{array}$ & $\begin{array}{l}401 \cdot 2 \\
401 \cdot 2\end{array}$ & $\begin{array}{l}377.7 \\
377.7\end{array}$ & $\begin{array}{l}0.193 \\
0.186\end{array}$ & $\begin{array}{l}849.9^{-} \\
832.1\end{array}$ \\
\hline $\begin{array}{l}164 \\
165\end{array}$ & $\begin{array}{l}\text { CHF } \\
98\end{array}$ & $\begin{array}{l}1200 \\
1200\end{array}$ & $\begin{array}{l}0.451 \\
0.451\end{array}$ & $\begin{array}{l}401.9 \\
401.9\end{array}$ & $\begin{array}{l}378.5 \\
378.5\end{array}$ & $\begin{array}{l}0.278 \\
0.273\end{array}$ & $\begin{array}{l}726.7 \\
720.4\end{array}$ \\
\hline $\begin{array}{l}166 \\
167\end{array}$ & $\begin{array}{l}\text { CHF } \\
98\end{array}$ & $\begin{array}{l}1200 \\
1200\end{array}$ & $\begin{array}{l}0.903 \\
0.903\end{array}$ & $\begin{array}{l}399.6 \\
399.6\end{array}$ & $\begin{array}{l}376.0 \\
376.0\end{array}$ & $\begin{array}{l}0.422 \\
0.409\end{array}$ & $\begin{array}{l}641.6 \\
633.4\end{array}$ \\
\hline 186 & $\operatorname{MAX} *$ & 1200 & 1.79 & 401.9 & 378.5 & 0.720 & 608.6 \\
\hline
\end{tabular}

* No CHF achieved at maximum power of generator. 
TABLE 2 (Continued)

\begin{tabular}{|c|c|c|c|c|c|c|c|}
\hline $\begin{array}{l}\text { RUN } \\
\text { NO. }\end{array}$ & PYPE & $\begin{array}{l}P_{R E S} \\
\text { (PS!A) }\end{array}$ & $\begin{array}{c}\text { MASS } \\
\text { VELOCITY } \\
X 10-6 \\
\text { (LB/HR } \\
\text { FTSO) }\end{array}$ & $\begin{array}{c}\text { INLET } \\
\text { TEMPER } \\
\text { ATURE } \\
\text { (DEQ,F, ) }\end{array}$ & $\begin{array}{l}\text { MEASURED } \\
\text { INLET } \\
\text { ENTHALPY } \\
\text { (BTU/LLA) }\end{array}$ & $\begin{array}{l}\text { AVERAGE } \\
\text { HEAT FLUX } \\
X 10-6 \\
\text { (BTU/HR- } \\
\text { FTSO) }\end{array}$ & $\begin{array}{l}\text { CALCUE } \\
\text { LATED } \\
\text { EXIT } \\
\text { ENTHALPY } \\
\text { (BTU/LB) }\end{array}$ \\
\hline $\begin{array}{l}178 \\
179\end{array}$ & $\begin{array}{l}\text { CHF } \\
98\end{array}$ & $\begin{array}{l}800 \\
800\end{array}$ & $\begin{array}{l}0.222 \\
0.222\end{array}$ & $\begin{array}{l}399.2 \\
399.2\end{array}$ & $\begin{array}{l}374,9 \\
374,9\end{array}$ & $\begin{array}{l}0,172 \\
0,164\end{array}$ & $\begin{array}{l}804.1 \\
784,1\end{array}$ \\
\hline $\begin{array}{l}180 \\
181\end{array}$ & $\begin{array}{l}\mathrm{CHF} \\
98\end{array}$ & $\begin{array}{l}800 \\
800\end{array}$ & $\begin{array}{l}0.444 \\
0.444\end{array}$ & $\begin{array}{l}4 \cap 0.1 \\
400.1\end{array}$ & $\begin{array}{l}375,9 \\
375,9\end{array}$ & $\begin{array}{l}0.240 \\
0.237\end{array}$ & $\begin{array}{l}678.5 \\
674: 7\end{array}$ \\
\hline $\begin{array}{l}182 \\
183\end{array}$ & $\begin{array}{l}\text { CHF } \\
98\end{array}$ & $\begin{array}{l}800 \\
800\end{array}$ & $\begin{array}{l}0.910 \\
0.970\end{array}$ & $\begin{array}{l}402,9 \\
402,9\end{array}$ & $\begin{array}{l}378,9 \\
378,9\end{array}$ & $\begin{array}{l}0,400 \\
0.396\end{array}$ & $\begin{array}{l}628.5 \\
626 \div 0\end{array}$ \\
\hline $\begin{array}{l}184 \\
185\end{array}$ & $\begin{array}{l}\text { CHF } \\
98\end{array}$ & $\begin{array}{l}800 \\
800\end{array}$ & $\begin{array}{l}1.79 \\
1.79\end{array}$ & $\begin{array}{l}400.2 \\
400.2\end{array}$ & $\begin{array}{l}375,9 \\
375,9\end{array}$ & $\begin{array}{l}0,673 \\
0,659\end{array}$ & $\begin{array}{l}591.0 \\
586: 5\end{array}$ \\
\hline
\end{tabular}




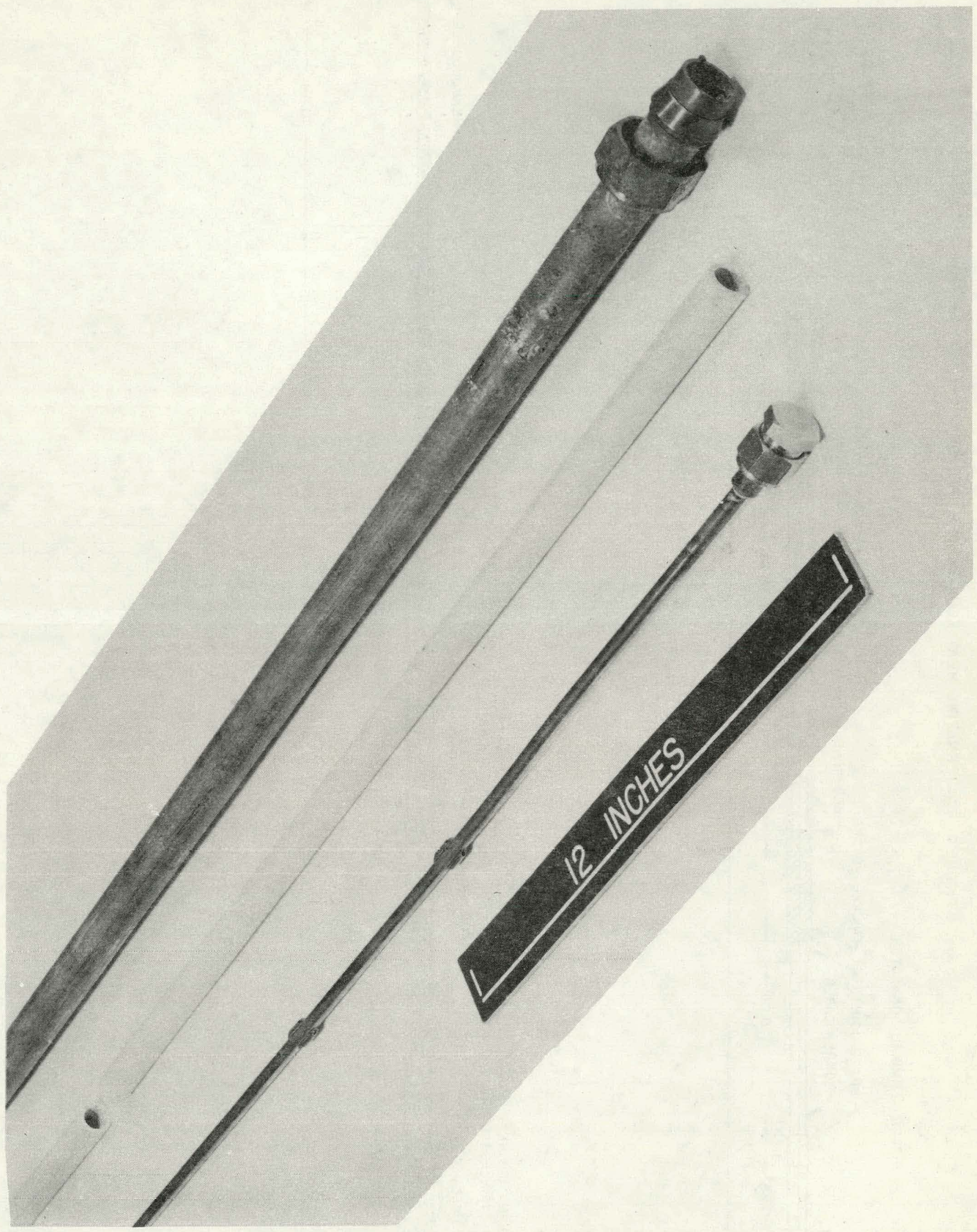

FIGURE 1: Partial Axial View of Alternating Heat Flux Test Section, Ceramic Housing and Backup Housing Negative No. 51944-2 
FIGURE 2. ALTERNATING HEAT FLUX HEATER ROD DETAIL
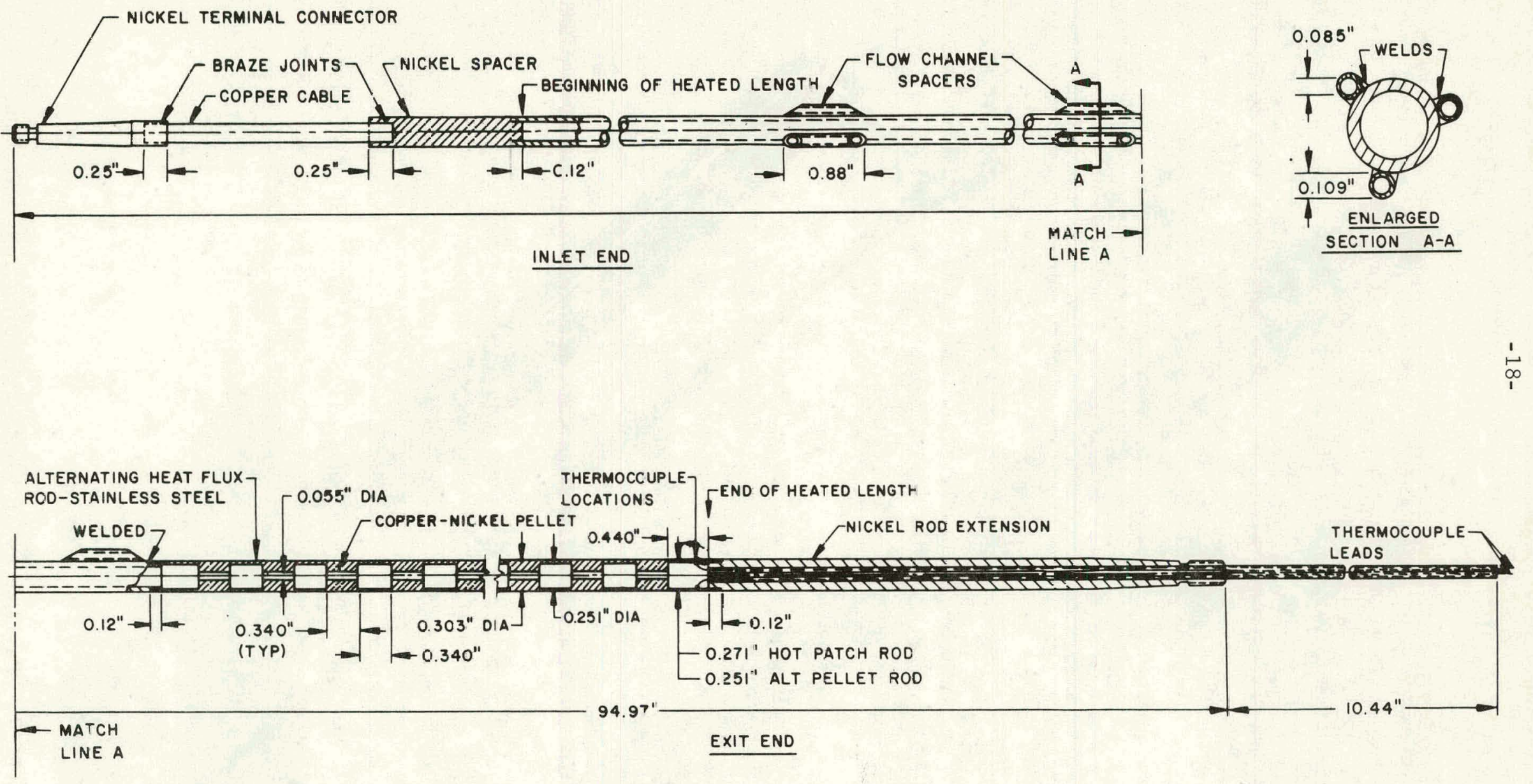
FIGURE 3: ALTERNATING HEAT FLUX TEST SECTION EXIT ASSEMBLY

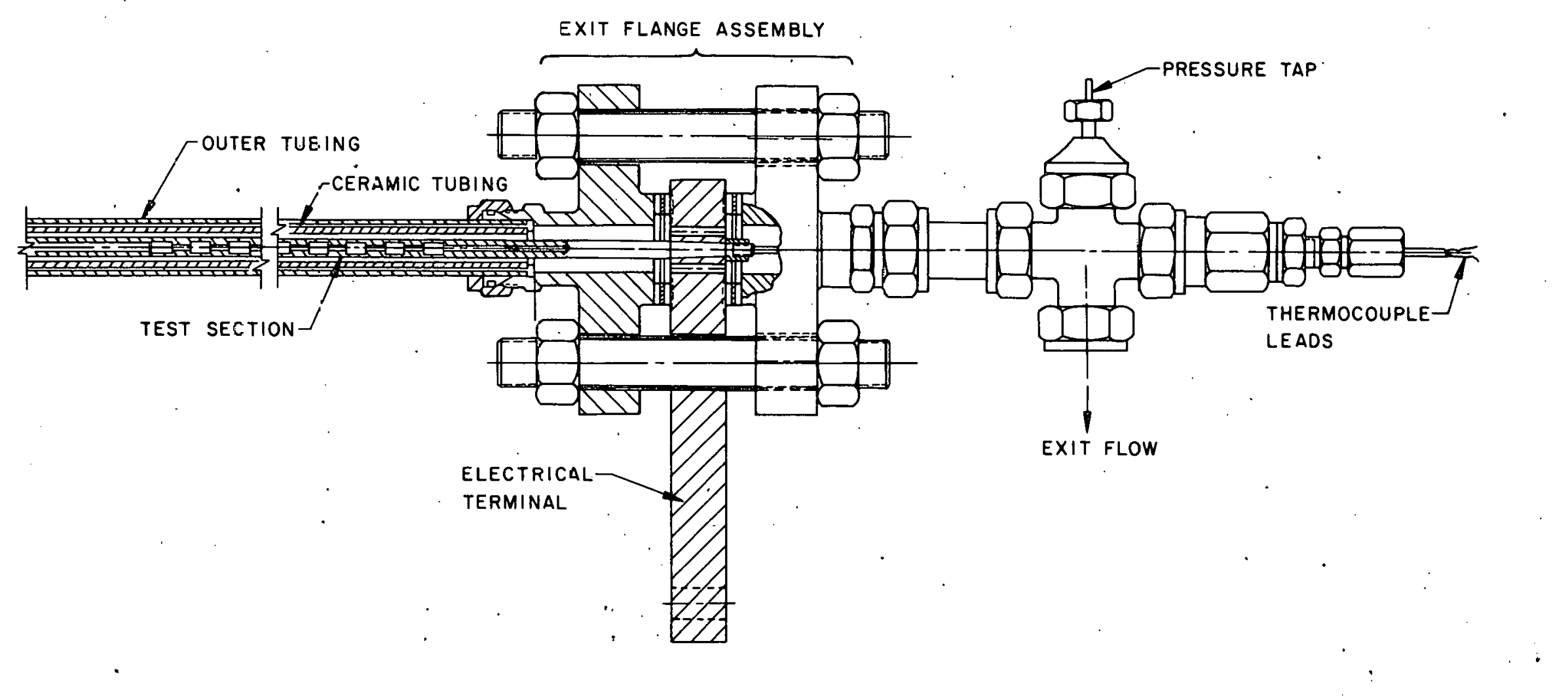


FIGURE 4: AXIAL HEAT FLUX PROFILE

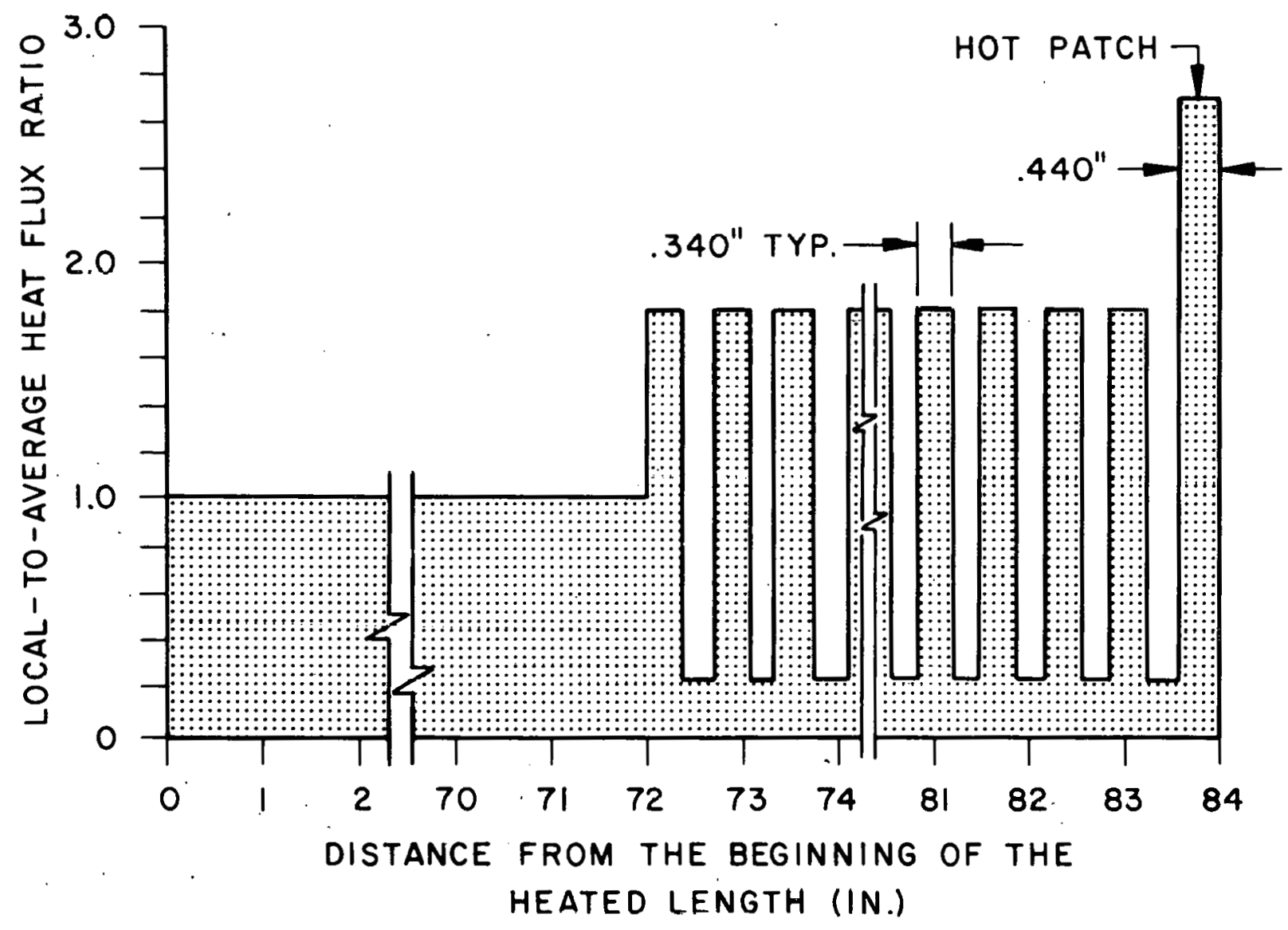


FIGURE 5: SCHEMATIC DIAGRAM OF. BETTIS LOOP NO. 29

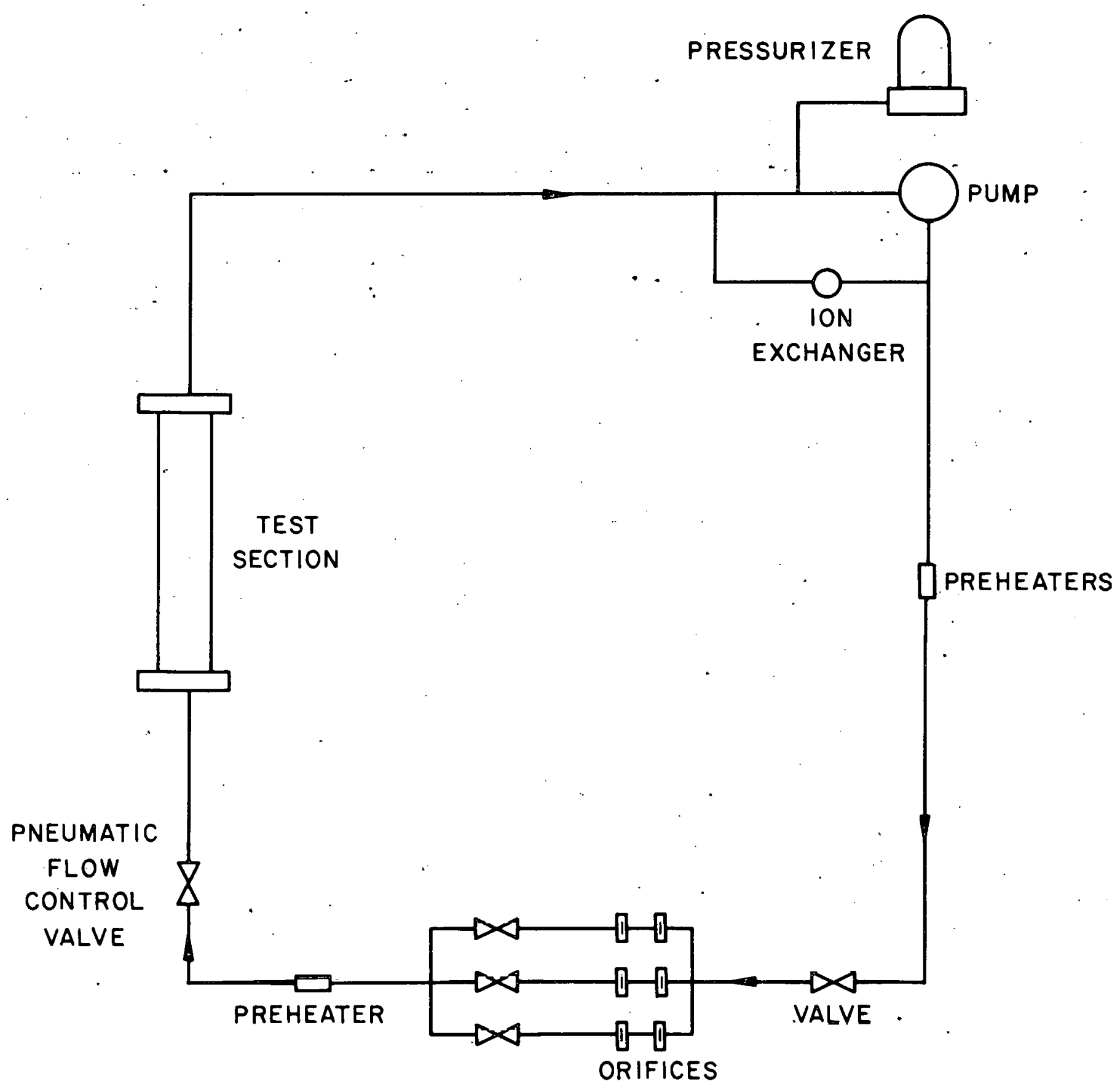


ALTERNATING HEAT FLUX TO UNIFORM HEAT FLUX CHF RATIO
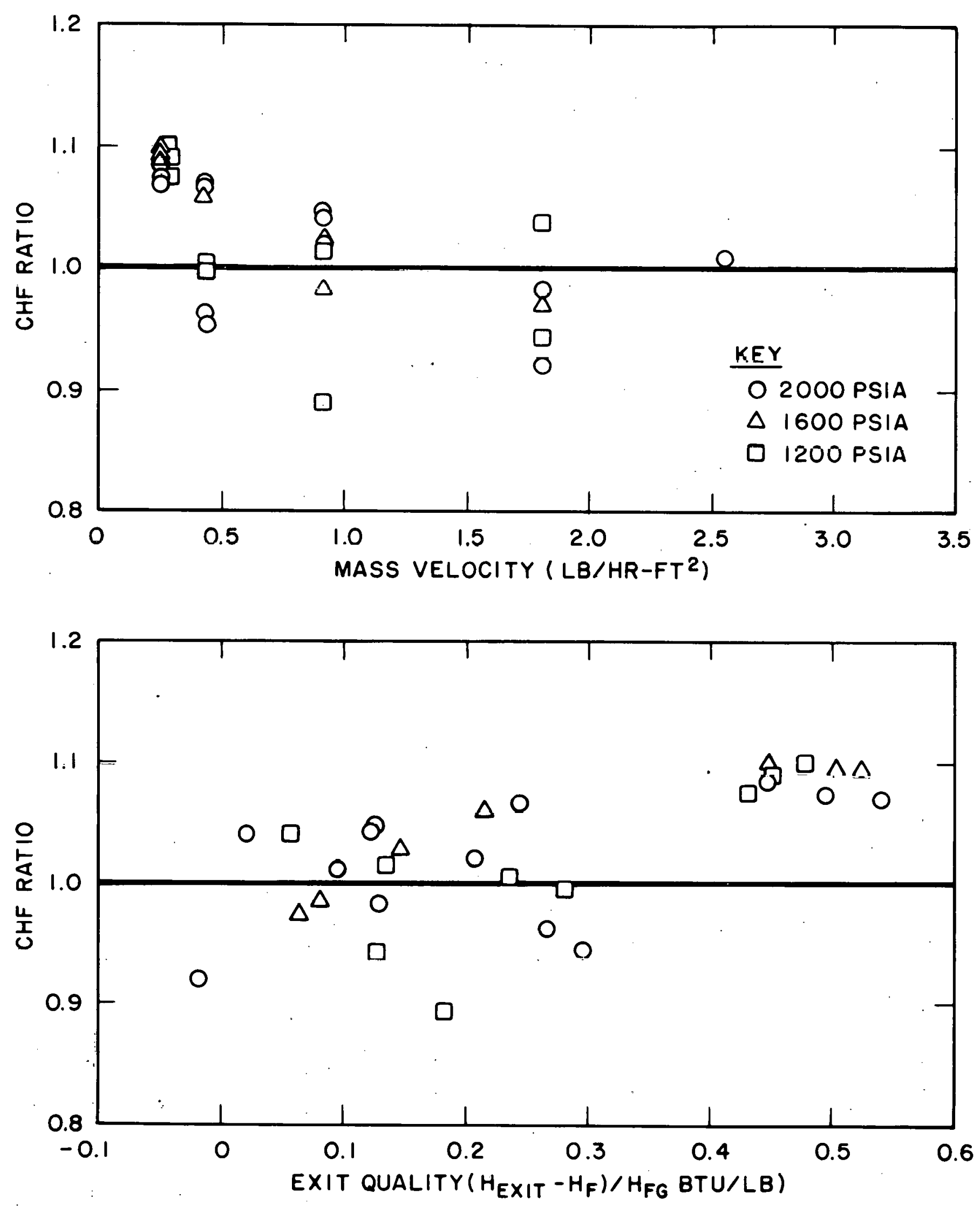

FIGURE 6 
$-23-$

ALTERNATING HEAT FLUX WITH HOT PATCH TO

ALTERNATING HEAT FLUX CHF RATIO -
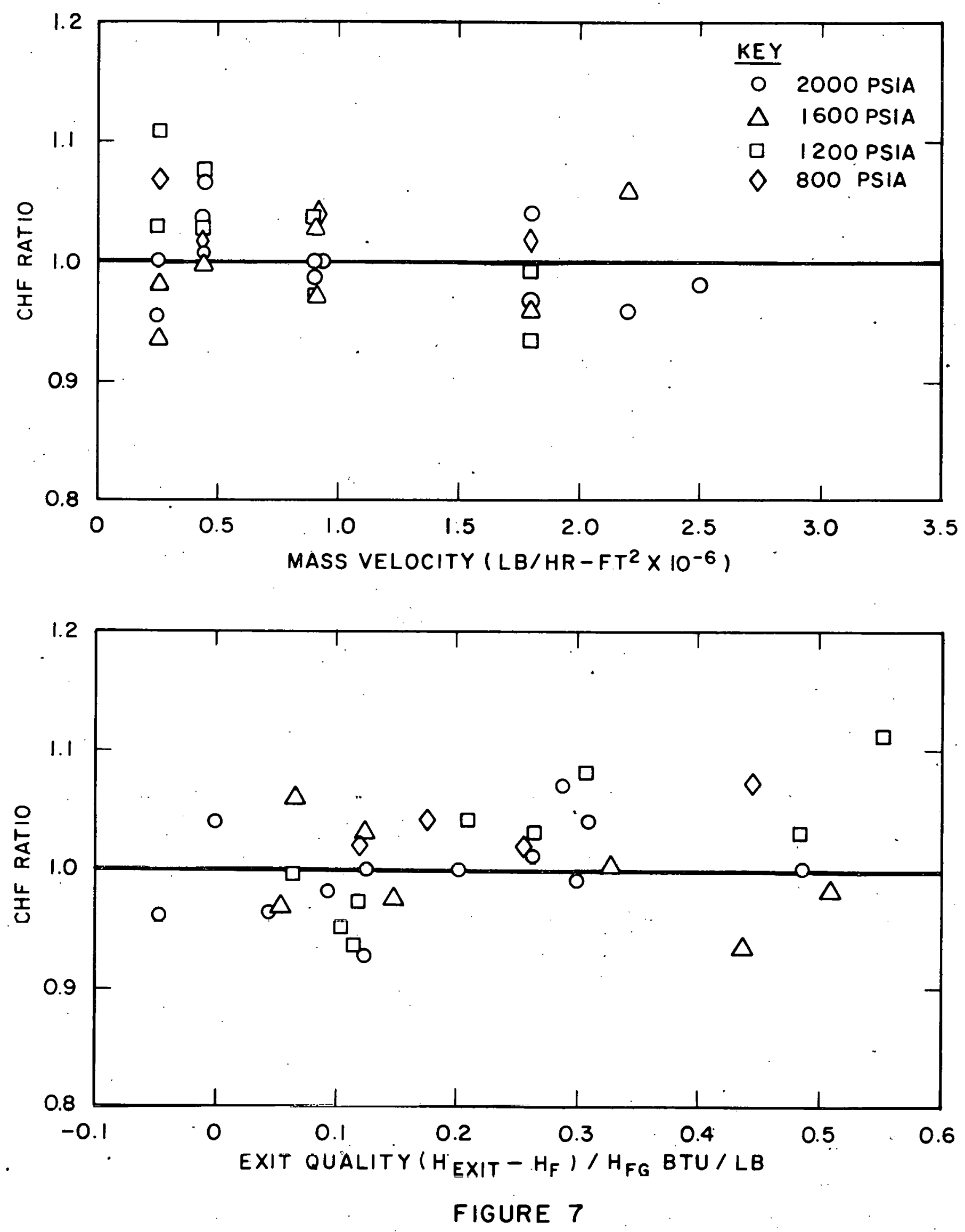
SUMMARY OF CHF DATA AT 2000 PSIA

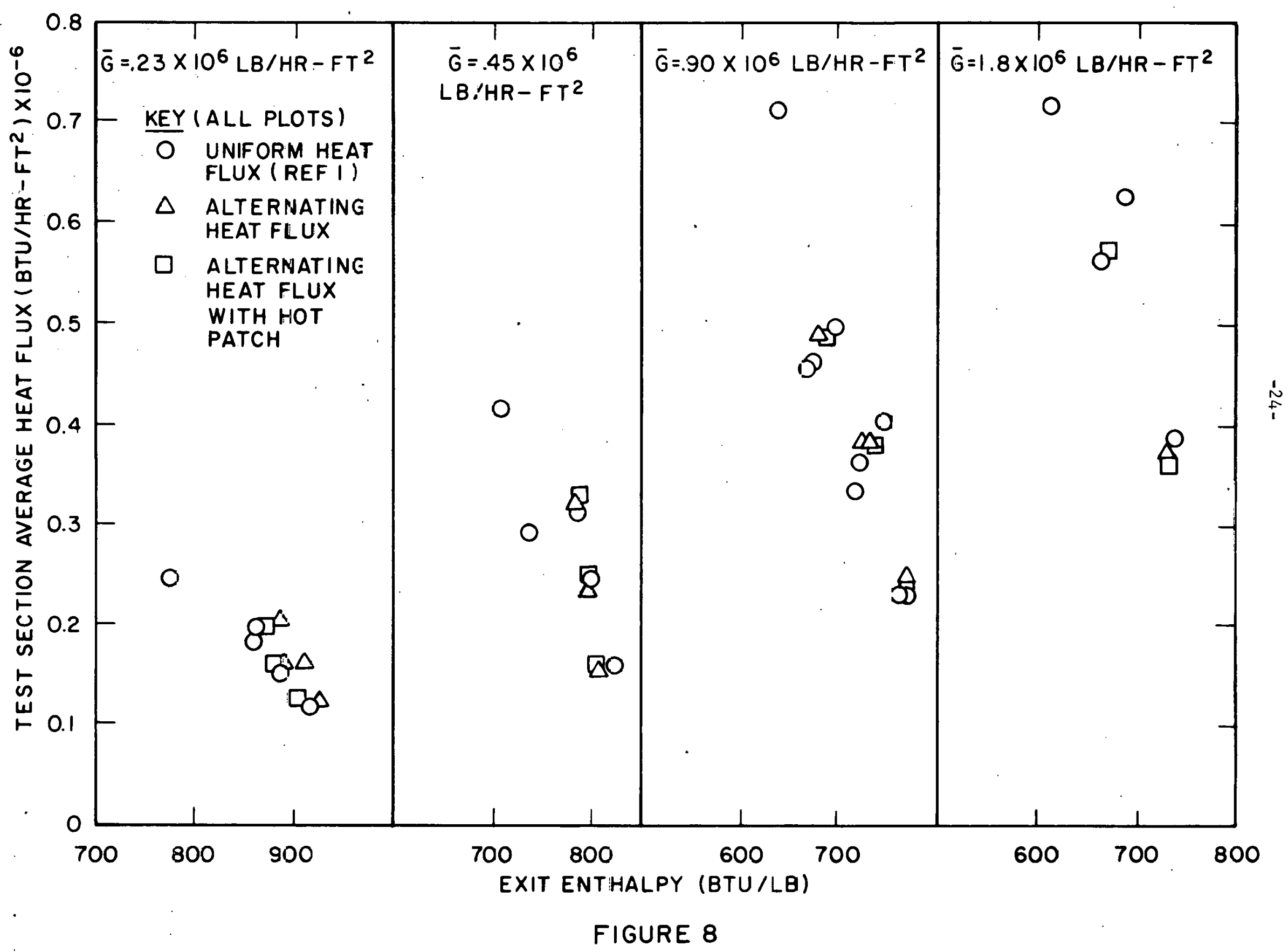


SUMMARY OF CHF DATA AT 1600 PSIA

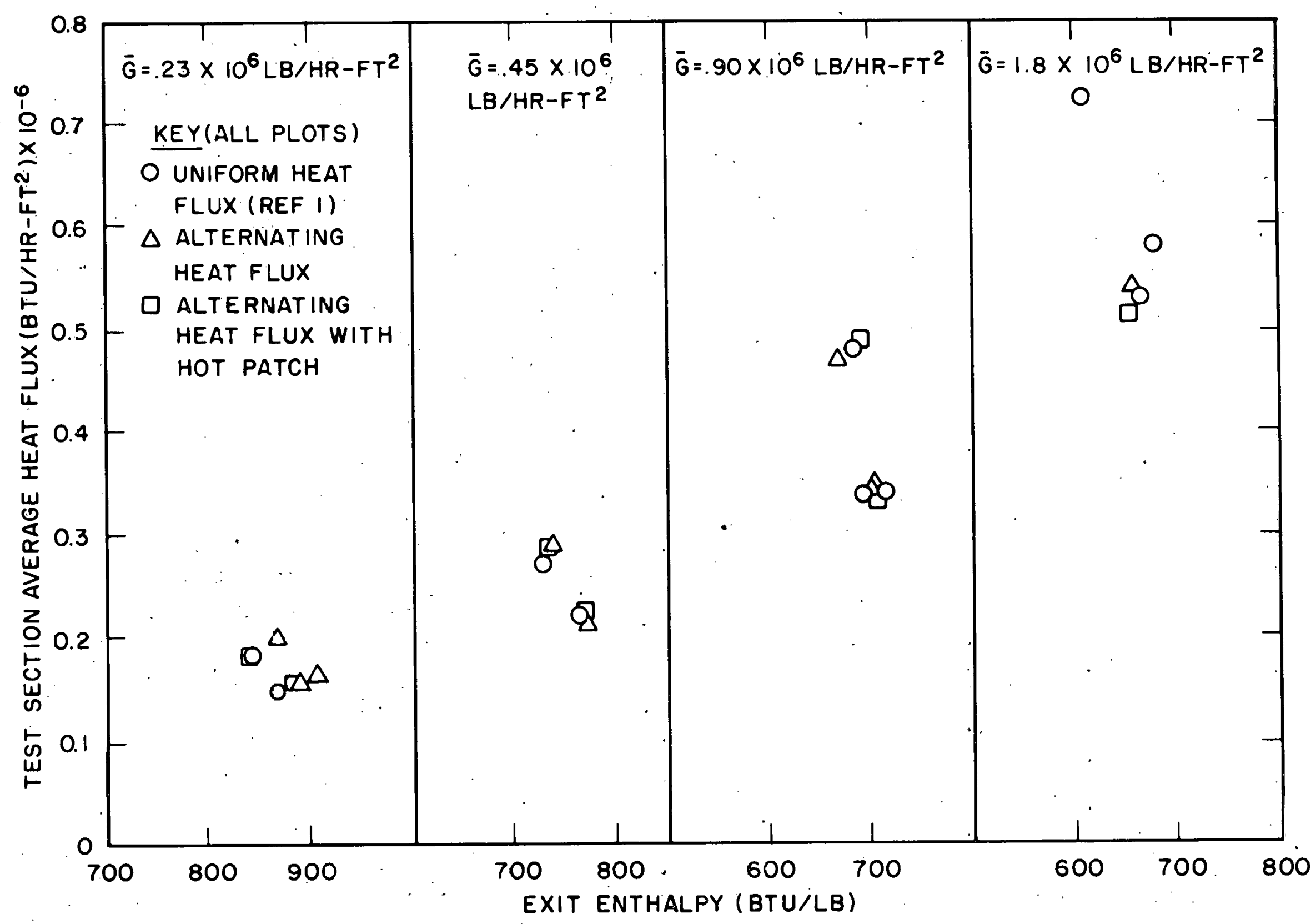

FIGURE 9 
SUMMARY CHF DATA AT 1200 PSIA

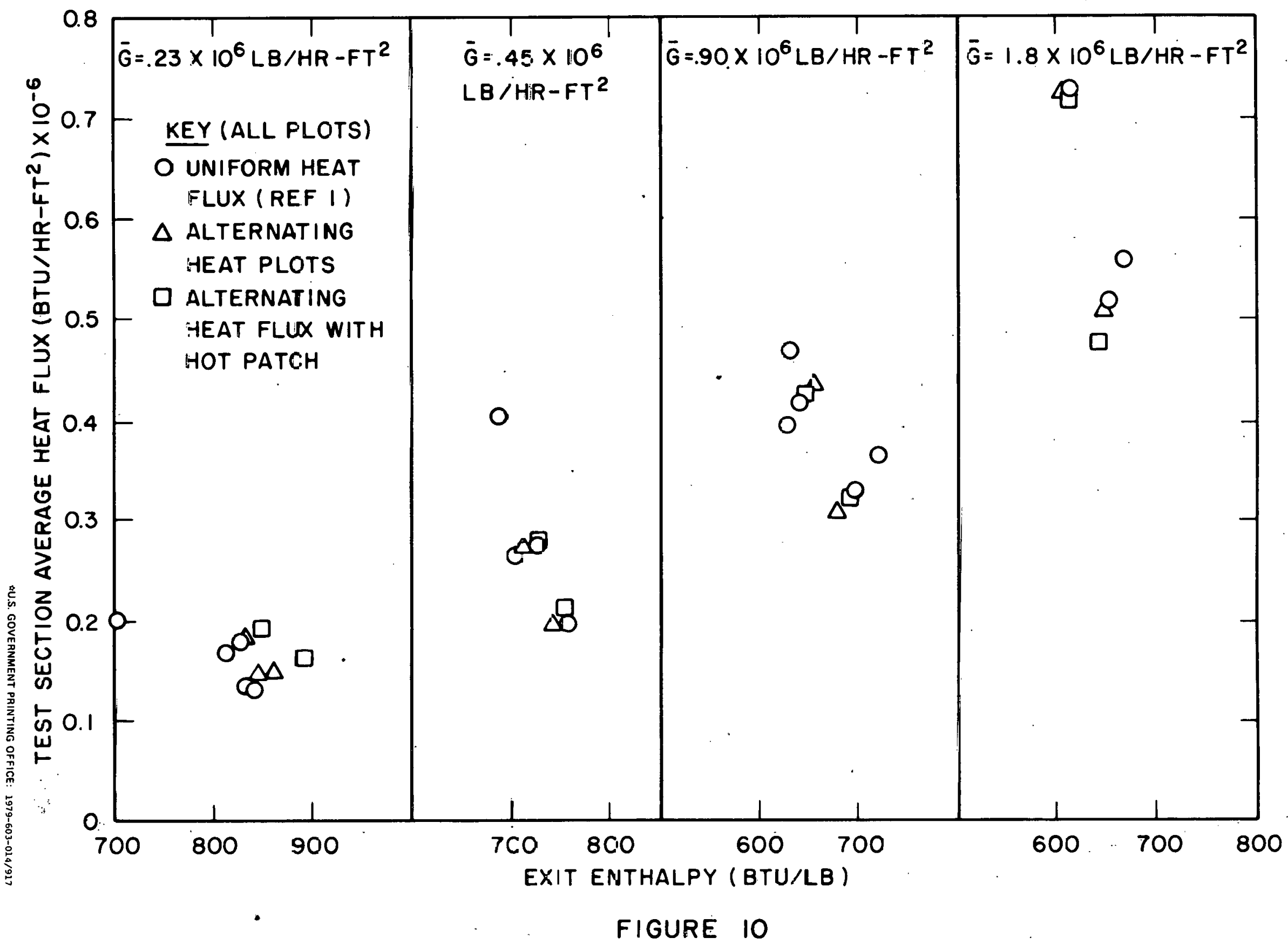

